\title{
Growth of the Archean sialic crust as revealed by zircon in the TTGs in eastern Finland
}

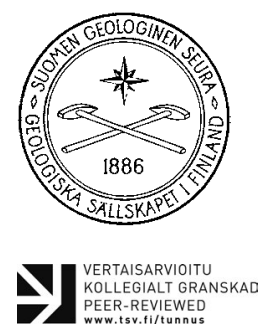
KOLLEGIALT GRANSKA
PEER-REVIIEWED
www.tsv.fi/tunnus

\author{
Pentti Hölttä ${ }^{\text {I* }}$, Irmeli Mänttäri ${ }^{\mathrm{I}, 3}$, Hannu Huhma ${ }^{\mathrm{I}}$, \\ Matti Kurhila ${ }^{\mathrm{I}}$, Tapio RuotoistenmäKi ${ }^{\mathrm{I}}$ and Asko Kontinen ${ }^{2}$ \\ ${ }^{1}$ Geological Survey of Finland. P.O. Box 96 FI-02151 Espoo, Finland \\ ${ }^{2}$ Geological Survey of Finland. P.O. Box 1237 FI-70211 Kuopio, Finland \\ ${ }^{3}$ Radiation and Nuclear Safety Authority, P.O. Box 14, FI-00811 Helsinki, Finland
}

\begin{abstract}
$\mathrm{U}-\mathrm{Pb}$ age determinations on zircon from granitoids in the Archean of eastern Finland were conducted using the SIMS, LA-ICP-MS and TIMS techniques, with an emphasis on low-HREE granitoids. The oldest rocks in the Fennoscandian Shield are 3.4-3.5 Ga. Several samples were collected close to these rocks, but none of the samples were as old, indicating that the oldest rocks are only small, possibly allochthonous fragments in the Neoarchean bedrock. Some tonalite-trondhjemite-granodiorite (TTG) samples yielded homogeneous $2.72-2.73 \mathrm{Ga}$ zircon populations, and in these samples, the initial $\varepsilon_{\mathrm{Nd}}$ was also close to the depleted mantle (DM) values. However, several granitoid samples with a main zircon population of $2.7-2.8 \mathrm{Ga}$ had $2.9-3.2 \mathrm{Ga}$ grains or inherited cores, and in some samples, all grains were of 2.9-3.0 Ga. In these samples, the $\varepsilon_{\mathrm{Nd}}$ value was also close to zero or slightly negative. These features suggest that apart from the juvenile Neoarchean magmas, the abundance of reworked $2.9 \mathrm{Ga}$ material is considerable in the Archean crust, which developed during successive juvenile magmatic inputs that melted and assimilated the older sialic crust. The lowHREE geochemical character of granitoids has no correlation with their age, with the low-HREE granitoids yielding an age span of 2.72-2.98 Ga.
\end{abstract}

Keywords: Archean, zircon, U-Pb age determination, Fennoscandian Shield, Finland

*Corresponding author (e-mail: pentti.holtta@gtk.fi)

Editorial handling: Alexander Slabunov (e-mail: slabunov@krc.karelia.ru)

\section{Introduction}

The Archean of the Fennoscandian Shield mostly consists of Neoarchean, 2.7-3.0 Ga tonalitictrondhjemitic-granodioritic (TTG) and volcanic- sedimentary complexes. Mesoarchean 3.0-3.6 Ga rocks are locally found, but Paleoarchean, 3.6$4.0 \mathrm{Ga}$ rocks have not been observed thus far, although some Paleoarchean zircon grains have been found in TTGs and overlying Proterozoic 
metasedimentary rocks (following the era classification by Griffin et al. (2014)). The oldest known rock in the Shield is the Siurua $3.50 \mathrm{Ga}$ trondhjemitic gneiss and the second oldest is the 3.40 Ga biotite gneiss paleosome of the Rasvamäki migmatite. Both are found near the western margin of the Karelia Province in the westernmost part of the Archean of the Fennoscandian Shield (Figs. 1-2). In addition, there are a few localities in the western and southeastern part of the Archean terrain, where TTG gneisses and amphibolites have yielded $3.10-3.20 \mathrm{Ga} \mathrm{U}-\mathrm{Pb}$ ages on zircon (Mutanen \& Huhma 2003; Svetov et al. 2004, 2006; Sergeev et al. 2007, 2008; Lauri et al. 2011; Smol'kin et al. 2011; Hölttä et al. 2014, 2019). However, in Karelia, most age determinations have been performed on the greenstone belts and adjacent rocks. Contrastingly, TTG ages have been relatively less investigated, and the temporal evolution of the TTG crust has therefore been poorly constrained. From the point of view of tectonic modelling, they are, however, crucial; for example, the validity of autochthonous or allochthonous models for the greenstone belts largely depends on the age of the surrounding TTG crust.

In this paper, we present new zircon U-Pb data for samples collected from TTG gneisses in the western part of the Karelia Province (Fig. 1). The main purposes of the study were as follows:

1) To gain a better idea of the regional extent of the Mesoarchean 3.40-3.50 Ga rocks, which is not well constrained. Actually, geodynamic modelling requires good knowledge of the terrane extension. For example, based on the existing sporadic zircon age determinations, models have been proposed in which coherent Paleoarchean microcontinents were constituents of the Archean crust of the Karelia Province (Mints 2014, 2015). However, arguments of this kind are not valid without geochronological databases having sufficient regional coverage.
Therefore, in this study, we dated several samples collected close to the known 3.403.50 Ga rocks to assess how large an area they do in fact cover.

2) To obtain more regional age data and better age constraints for the TTGs in the western Karelia Province, with an emphasis on low heavy rare earth element (HREE) granitoids. Although quite a few age determinations exist for the Archean granitoids, the emphasis has been on the TTGs in the greenstone belts, and most TTGs have been dated using thermal ionization mass spectrometry (TIMS) from bulk zircon (Hölttä et al. 2012). In this work, we conducted single-grain age determinations using laser ablation and secondary ion mass spectrometers, giving better estimates for the real age spread of zircon in the studied samples.

Halla et al. (2009) divided the Archean juvenile granitoids in the western Karelia Province into low-HREE TTGs, highHREE TTGs and sanukitoids. The geochemical signatures (e.g., low HFSE, high $\mathrm{Sr} / \mathrm{Y}$ and high $\mathrm{La} / \mathrm{Yb}$ ) of the lowHREE or 'adakitic' TTGs have often been interpreted to reflect deep melting of mafic precursors (e.g., Moyen (2009)). Consequently, further interpretations have been made of those tectonic processes that could create deep melting, such as subduction (Martin et al. 2005; Moyen 2011; Moyen \& Martin 2012) or drip tectonics (Nebel et al. 2018). In general, the adakitic granitoids are not confined to any geological setting, but in a certain area, their age distribution could be important from the point of view of tectonic models. If, for example, they were restricted in the Karelia Province to a particular time span, we could conclude that at that time, high-pressure melting prevailed. This information could then contribute to the construction of relevant geological models for the Archean. 


\section{Geological setting}

\subsection{Archean provinces}

The Archean of Fennoscandia is traditionally divided into the Norrbotten, Murmansk, Kola, Belomorian and Karelia Provinces (Fig. 1) (Slabunov et al. 2006; Hölttä et al. 2014). The boundaries between the provinces are in most cases blurred, and the division is based on certain lithological, structural and age characteristics, typical for each province. Lobach-Zhuchenko et al. (2005), Slabunov et al. (2006) and Hölttä et al. (2014) subdivided the Karelia Province into three terranes or subprovinces: the Vodlozero, Central Karelia and Western Karelia subprovinces (Fig. 1). Among the important distinctive characteristics of the Karelia subprovinces are that, based on existing age determinations, Mesoarchean 3.20-3.00 Ga volcanic rocks and granitoids are common in the Vodlozero subprovince and are also found in the Western Karelia subprovince, whereas granitoids and volcanic rocks of the greenstone belts in the Central Karelia subprovince are Neoarchean, $\leq 2.80 \mathrm{Ga}$, although they may locally contain recycled Mesoarchean crustal material (Vaasjoki et al. 1993). The Belomorian Province east of the Karelia Province largely consists of 2.72-2.93 Ga TTG gneisses, greenstones and paragneisses. Locally ophiolite-like rocks (Shchipansky et al. 2004) and eclogites are found, which have not yet been reported elsewhere in the Archean of the Fennoscandian Shield (Volodichev et al. 2004; Mints et al. 2010; Balagansky et al. 2015; Dokukina et al. 2017; Dokukina \& Mints 2019).

\subsection{Western Karelia Subprovince in Finland}

The Western Karelia Subprovince, comprising much of eastern Finland and the westernmost part of Russian Karelia, is a diverse mosaic of rock units with an age span of almost one billion years. Migmatitic TTG orthogneisses and amphibolites predominate, with a few medium and low-pressure granulite terrains in the Iisalmi and Pudasjärvi areas (Fig. 2) (Hölttä et al. 2000a). Paragneisses (Laajoki 1991; Kontinen et al. 2007) are minor constituents of the bedrock (Fig. 2). Large, 2.72-2.74 Ga sanukitoid intrusions are found in the Ilomantsi area (Fig. 2) (Halla 2005; Heilimo et al. 2010, 2011, 2012, 2013).

In the Finland area, there are three major Archean greenstone belts: the Ilomantsi belt, Kuhmo-Suomussalmi belt and Oijärvi belt (Fig. 2). In the Ilomantsi belt, the youngest volcanic rocks are dated at $2.75 \mathrm{Ga}$, but felsic metavolcanic rocks as old as $2.88 \mathrm{Ga}$ are found. In the KuhmoSuomussalmi belt, the dates of the volcanic rocks are 2.79-2.94 Ga and in the Oijärvi belt 2.80-2.82 Ga (Huhma et al. 2012a; Lehtonen et al. 2016, 2017). The Ilomantsi belt differs from the other belts in many aspects. The abundance of metasedimentary rocks is high and arc-type felsic and intermediate volcanic rocks are more common than mafic volcanic rocks, whereas the Kuhmo-Suomussalmi and Oijärvi belts mostly consist of oceanic plateautype mafic and ultramafic rocks (Maier et al. 2013; Hölttä et al. 2014).

\subsubsection{Age distribution of granitoids}

Apart from the greenstone complexes and adjacent TTGs, the radiometric age determinations have a rather poor regional cover in the Western Karelia Subprovince. In the NW part of Western Karelia, the Siurua trondhjemitic gneiss was dated at $3.50 \mathrm{Ga}$, which is the oldest age so far reported in the whole Fennoscandian Shield (Mutanen \& Huhma 2003; Lauri et al. 2011). TTG gneisses of $3.20 \mathrm{Ga}$ are found in a few localities in the Iisal$\mathrm{mi}$ area, often having mafic intercalations that compositionally resemble enriched mid-ocean ridge (E-MORB)-type basalts (Hölttä et al. 2000a, 2012; Mänttäri \& Hölttä 2002; Lauri et al. 2011). A few age determinations have yielded ages from 2.95-2.97 Ga in TTGs in the northern and northwestern parts of the Province (Mutanen \& Huhma 2003, Mikkola et al. 2011). TTGs of 2.78-2.82 Ga and $2.74-2.76 \mathrm{Ga}$ are common all over (Pietikäi- 




Figure 1. A generalised geological map of Fennoscandia, simplified from Koistinen et al. (2001). For simplicity, all Proterozoic areas are presented with the same colour. Yellow dots indicate the sampling sites for this paper. Dashed lines denote the approximate boundaries of the Archean provinces. Because of the Proterozoic cover, the boundaries of the Norrbotten Province are not outlined. TTG = tonalite-trondhjemite-granodiorite. White colours denote sea and lake areas.

nen \& Vaasjoki 1999; Vaasjoki et al. 2001; Lauri et al. 2006; Mikkola et al 2011; Hölttä et al. 2012). Sanukitoids, dated at ca. 2.72-2.75 Ga, cover large areas in eastern Finland (Fig. 2) (Halla 2005; Heilimo et al. 2012). A specific age group is formed by
2.70-2.72 Ga enderbites, quartz diorites and diorites that are found in the western part of the Western Karelia Subprovince (Hölttä 1997; Mänttäri \& Hölttä 2002; Mutanen \& Huhma 2003; Paavola 2003; Mikkola et al. 2011; Hölttä 




Figure 2. Generalised lithological map of the Archean of the NW Karelia Province in Finland. For simplicity, the Paleoproterozoic lithologies are combined together. Yellow dots indicate the sampling sites. White dots denote the sampling sites for the Siurua 3.5 Ga trondhjemitic gneiss and the Rasvamäki 3.4 Ga migmatite. TTG = tonalite-trondhjemite-granodiorite, GGM = granitegranodiorite-monzogranite. KSB = Kainuu Schist Belt.

et al. 2012). The youngest granitoids are widespread, ca. 2.63-2.70 Ga granitic-granodioritic-monzogranitic (GGM) rocks that are related to large-scale crustal melting and high-grade metamorphism (Hölttä et al. 2000a; Mänttäri \& Hölttä 2002; Mu- tanen \& Huhma 2003; Lauri et al. 2006; Käpyaho et al. 2007; Mikkola et al. 2011; Hölttä et al. 2012). The youngest Archean igneous rock is the $2.61 \mathrm{Ga}$ Siilinjärvi carbonatite in the western margin of the Karelia Province (O’Brien et al. 2015). 


\section{Methods and materials}

\subsection{Analytical methods}

Ages were determined by using secondary ion mass spectrometry (SIMS), thermal ionization mass spectrometry (TIMS) and laser ablation inductively coupled plasma mass spectrometry (LA-ICP-MS). The analyses were performed over a decade and the latter facility became available during that time, which was the reason for the usage of several age determination methods.

TIMS analyses were performed at the Geological Survey of Finland, Espoo. Samples for analysis were washed, crushed, washed again using a Wilfley table, and treated with methylene iodide and Clerici ${ }^{\oplus}$ solutions to separate the heavy minerals. Non-magnetic heavy fractions were separated with a Frantz isodynamic separator. Zircons were selected for analysis by hand picking. The analytical methods for the Sm-Nd and $\mathrm{U}-\mathrm{Pb}$ analyses are described in Huhma et al. (2012a, 2012b).

SIMS analyses were performed on zircon mounted in epoxy, subsequently polished and coated with gold. The SIMS U-Pb isotope analyses were performed using the Nordic Cameca IMS 1270 (Nordsim) at the Swedish Museum of Natural History, Stockholm, Sweden. The spot diameter for the $8 \mathrm{nA}$ primary $\mathrm{O}_{2}$ ion beam was $-20 \mu \mathrm{m}$ and oxygen flooding in the sample chamber was used to increase the production of $\mathrm{Pb}^{+}$ions. Three counting blocks, each including four cycles for $\mathrm{Zr}, \mathrm{Pb}, \mathrm{Th}$ and $\mathrm{U}$, were measured from each spot. The mass resolution $(\mathrm{M} / \Delta \mathrm{M})$ was $5400(10 \%)$. The raw data were calibrated against the zircon standard 91500, which has an age of $1065 \mathrm{Ma}$ (Wiedenbeck et al. 1995), and corrected for modern common lead $(\mathrm{T}=0)$ (Stacey \& Kramers 1975). For the detailed analytical procedure, see Whitehouse et al. (1999) and Whitehouse \& Kamber (2005).

The LA-ICP-MS analyses of separated zircon fractions (samples A1887-A1890) were performed using both a Nu Plasma HR multicollector ICPMS and a $\mathrm{Nu}$ Plasma AttoM single-collector ICP-MS at the Geological Survey of Finland, Espoo. The
LA-ICP-MS analyses from 40- $\mu$ m-thick polished sections were performed using single-collector ICP-MS.

In multicollector ICP-MS analyses, the normal ablation conditions were beam diameter $25 \mu \mathrm{m}$, pulse frequency $10 \mathrm{~Hz}$ and beam energy density $1.4 \mathrm{~J} / \mathrm{cm} 2$. Standard zircons GJ-01 $(609 \pm 1 \mathrm{Ma}$; Belousova et al. 2006) and an in-house standard, A1772 (2712 $\pm 1 \mathrm{Ma}$, Huhma et al. (2012b)), were used for calibration. The analytical procedure is described in detail in Huhma et al. (2012b).

The Nu Plasma AttoM single-collector ICP-MS was connected to a Photon Machine Excite laser ablation system. Typical ablation conditions were beam diameter $20 \mu \mathrm{m}$, pulse frequency $5 \mathrm{~Hz}$ and beam energy density $2 \mathrm{~J} / \mathrm{cm} 2$. Age-related common lead correction was used when the analysis revealed common lead contents significantly above the detection limit (i.e., >50 cps). The in-house standard A382 (zircon) was run at the beginning and end of each analytical session and at regular intervals during sessions.

Plotting of the $\mathrm{U}-\mathrm{Pb}$ isotopic data, fitting of the discordia lines and age calculations were performed using Isoplot/Ex 4.15 software (Ludwig 2012). Age errors were calculated at $2 \sigma$ and decay constants errors were ignored. Data-point error ellipses in the figures are $2 \sigma$. The chemical analyses were conducted in the laboratory of Labtium Ltd using XRF and ICP-MS, as described in Rasilainen et al. (2007). Back-scattered electron (BSE) images of zircon grains were taken using a model JEOL JSM5900 LV scanning electron microscope (SEM) at the Geological Survey of Finland. The SEM was equipped with an energy dispersive X-ray spectrometer (EDS) with INCA Feature phase detection and classification software.

\subsection{Samples and sampling localities}

Separated zircon grains were analysed from eight samples using the Nordsim secondary ion microprobe. Chemical analyses of the samples were first published in the Rock Geochemical Database of the Geological Survey of Finland 
(Rasilainen et al. 2007). Six of these were from the northern and northwestern part of the Western Karelia Subprovince. These samples represent geochemically low-HREE types with fractionated REE patterns (Fig. 3) and high $\mathrm{Sr} / \mathrm{Y}$ and $\mathrm{La} / \mathrm{Yb}$ ratios (Ruotoistenmäki 2019). Two samples were from sanukitoids in the Ilomantsi area. These have geochemical similarities with high-silica adakitic rocks, apart from their higher $\mathrm{K}, \mathrm{Ba}$ and $\mathrm{Sr}$ contents (Halla 2005; Heilimo et al. 2012). The rock type of the samples was defined from the CIPW norm calculated from the chemical analysis, using the classification by Barker (1979), which discriminates tonalites from trondhjemites (Fig. 4). A summary
Figure 3.

a) Primitivemantle-normalised spider diagram for the samples with separated zircon fractions. Normalising factors are from Sun and McDonough (1989); b) chondritenormalized REE patterns for the same samples. Chondrite normalising factors are from Boynton (1984).
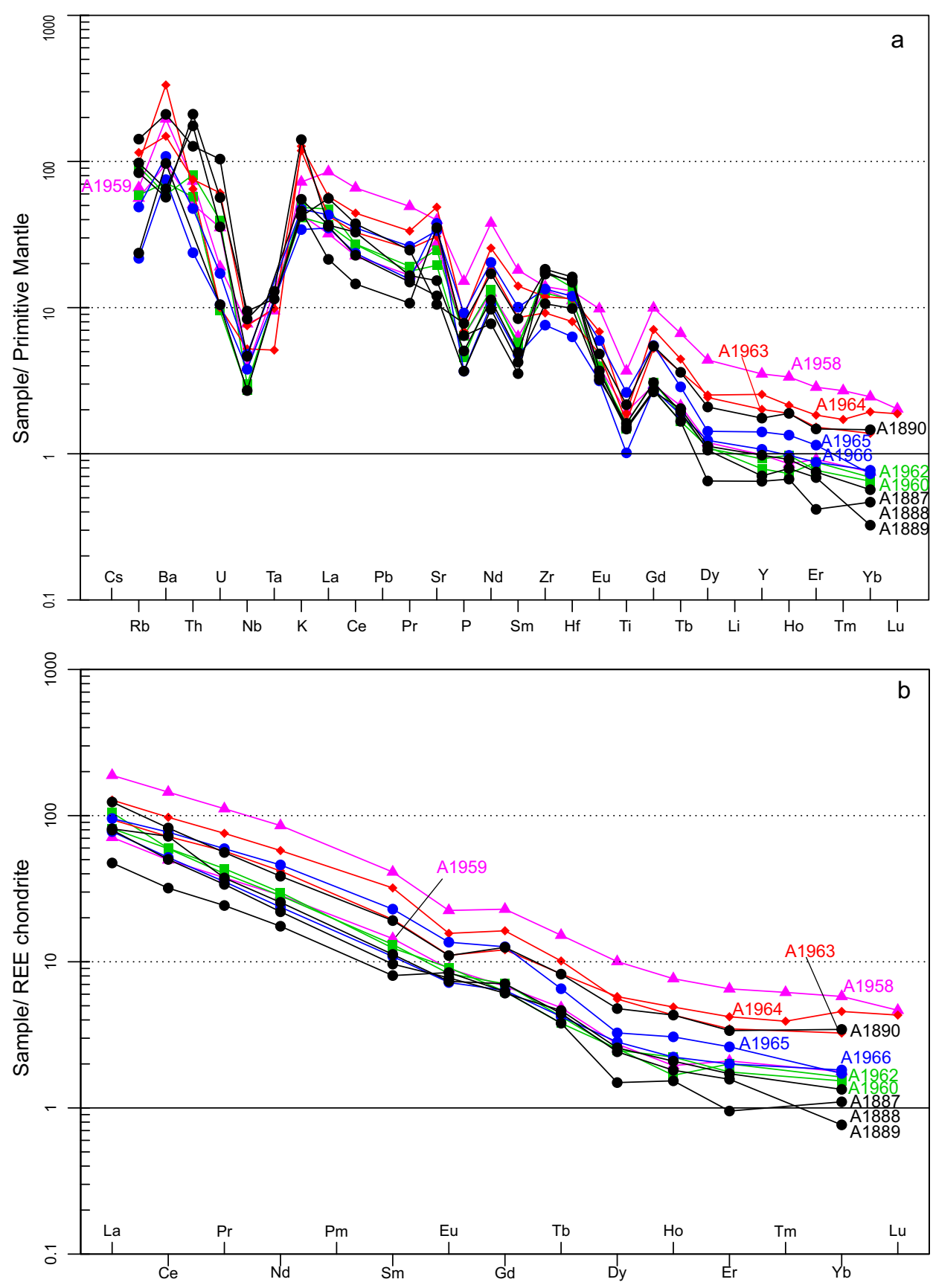


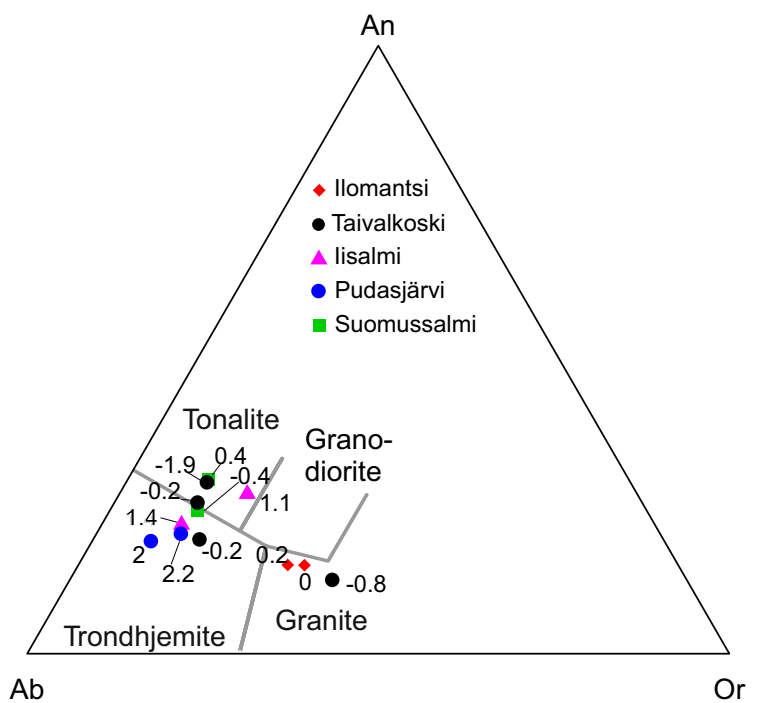

Figure 4. Normative anorthite (An)-albite (Ab)-orthoclase (Or) classification triangle (Barker 1979) for the analysed samples. The numbers next to the symbols indicate the $\varepsilon \mathrm{Nd}$ values.

of the samples with locations is given in Electronic Appendix A, and the chemical whole-rock analyses are presented in Electronic Appendix B. Field photographs of some of the sampling sites are provided in Electronic Appendix C.

Altogether, 21 samples were analysed in this study using LA-ICP-MS. Four datings were performed from separated zircon fractions from TTG gneisses in the Taivalkoski area, the sampling sites of which are located ca. $60-100 \mathrm{~km}$ east of Siurua (Figs. 1-2). Three of these samples were first dated using TIMS. The results were checked using both multicollector and single-collector LA-ICPMS. The Siurua and Taivalkoski areas are separated by shear zones and a narrow Paleoproterozoic schist belt, namely the Kainuu Schist Belt (Fig. 2), but lithologically the two areas have some similarities. For example, orthopyroxene-bearing granulite facies orthogneisses are found in both terrains (Lalli 2002; Hölttä et al. 2012) (Fig. 2).

In order to investigate the regional distribution of the oldest rocks, 11 specimens were taken 4-36 $\mathrm{km}$ from the Rasvamäki 3.40 Ga migmatite and six specimens were taken $12-40 \mathrm{~km}$ from the Siurua
3.50 Ga trondhjemitic gneiss. From these samples, zircon was directly dated from thin sections using single-collector LA-ICP-MS.

\section{Results}

\subsection{U-Pb age results and interpretation}

Below, the results are presented according to the area. A summary of the results with interpretations is provided in Table 1. The analytical data from the SIMS analyses are presented in Electronic Appendix D. BSE images of selected analysis spots are displayed in Fig. 5. The analytical data from multicollector LA-ICP-MS are provided in Electronic Appendix $\mathrm{E}$ and the data for singlecollector LA-ICP-MS in Electronic Appendix F. Selected BSE images of the analysed zircon grains are presented in Electronic Appendices E and G. The analytical LA-ICP-MS data for the zircon dated from thin sections are presented in Electronic Appendix $\mathrm{H}$, and selected BSE images of the analysed zircon grains are displayed in Electronic Appendix I.

\section{2. lisalmi-Rasvamäki}

\subsubsection{SIMS analyses}

A1958. The A1958 tonalite contains abundant zircon crystals with a fairly heterogeneous population in the $>4.2 \mathrm{~g} \mathrm{~cm}^{-3}$ density fraction. These are either prismatic euhedral or subhedral, brown to colourless, and transparent to translucent. The grains are rather small with a somewhat variable grain size $(50-500 \mu \mathrm{m})$. Grains with metamict (reddish, turbid) cores are frequent. Apatite and epidote are common inclusions. In BSE images, the zircon crystals are zoned with frequent fractures and inclusions. The centre domains are often altered and zoning-related alteration is common. Many grains show rather structurally homogeneous outer zones/ rims (Fig. 5a-b). 


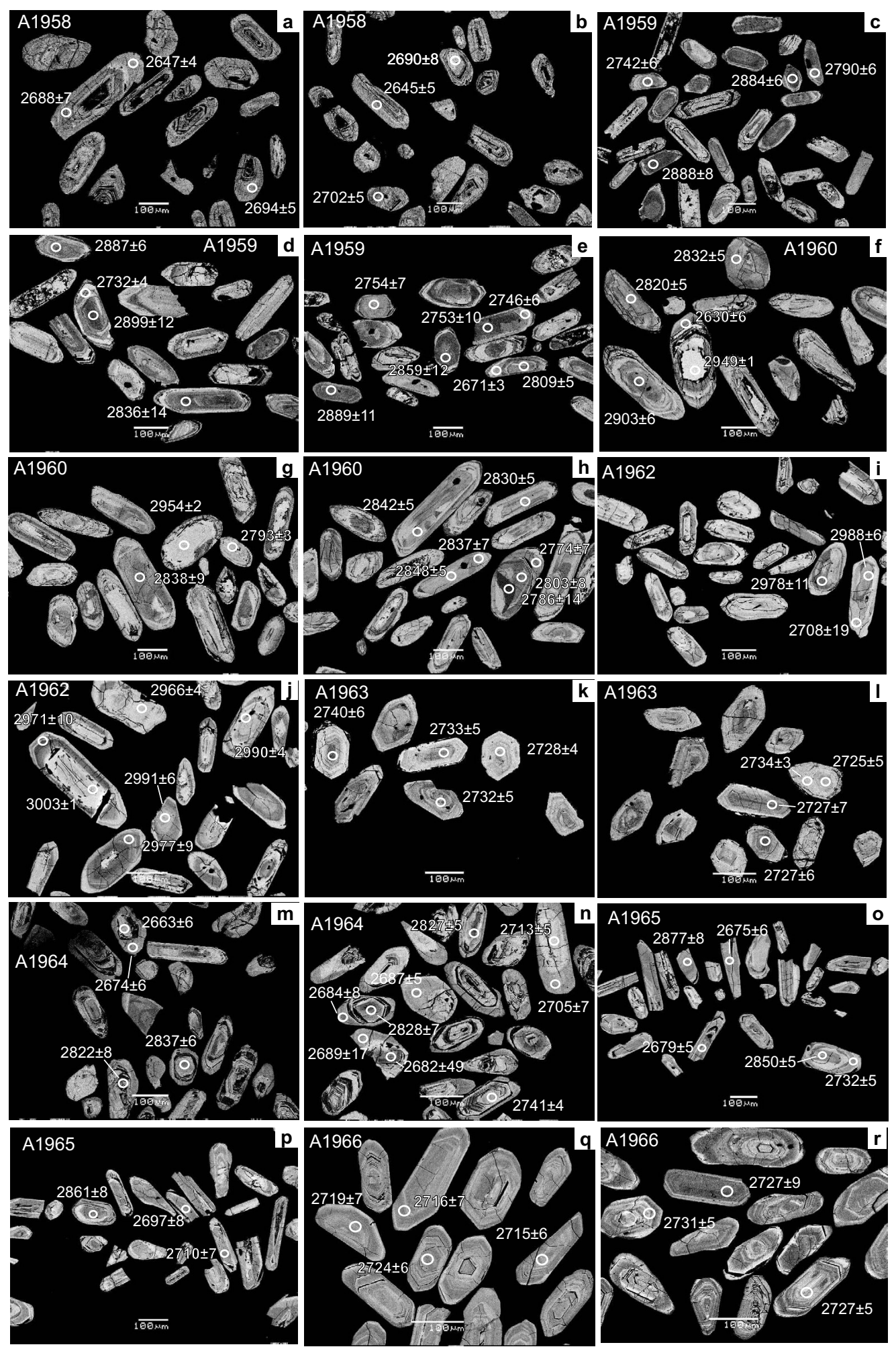

Figure 5. Back-scattered electron images of selected zircon grains dated using an ion microprobe. The circles indicate the analysis spots, with the ${ }^{207} \mathrm{~Pb} /{ }^{206} \mathrm{~Pb}$ age next to the spot. 


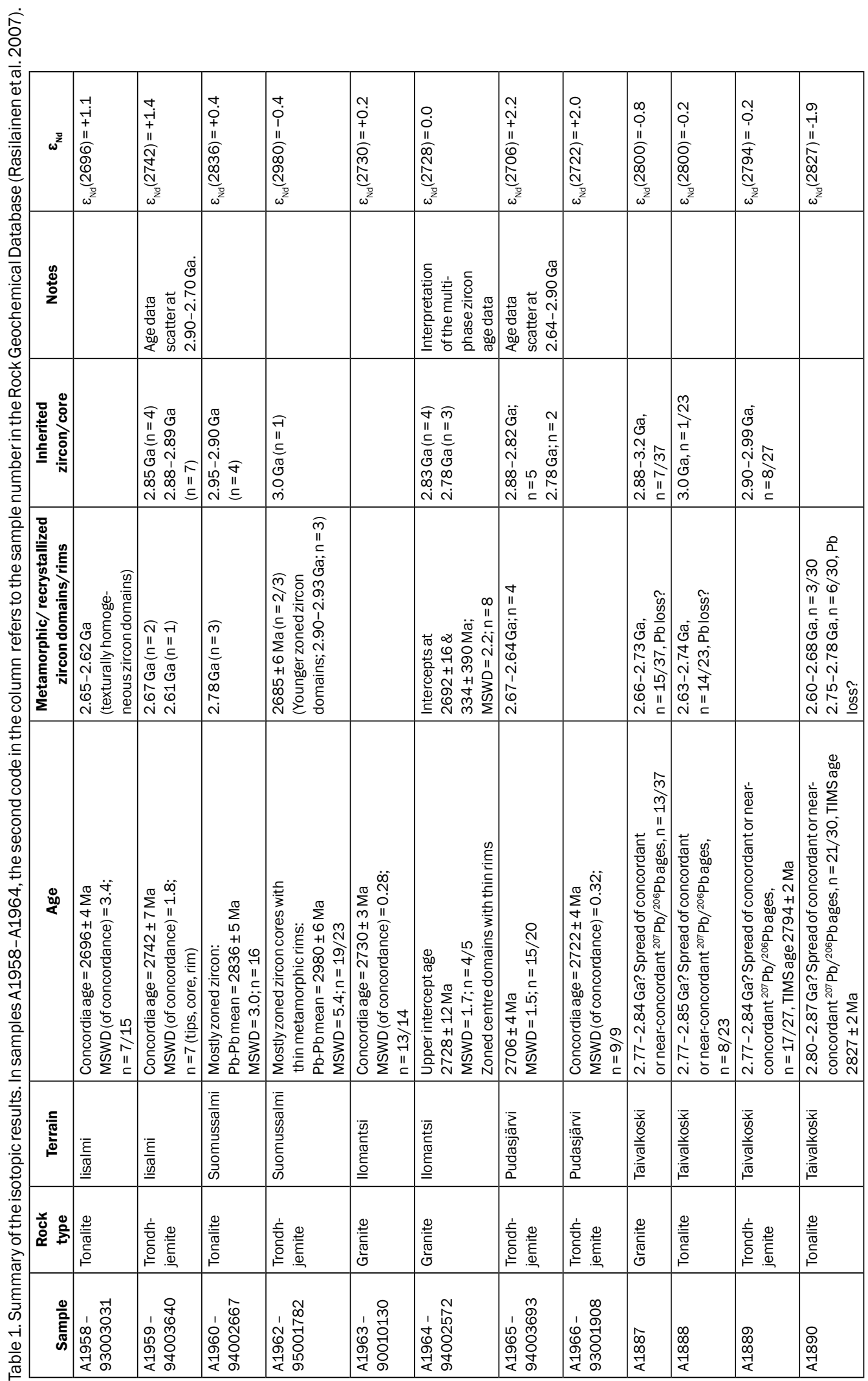




\begin{tabular}{|c|c|c|c|c|c|c|c|c|c|c|c|c|c|c|c|}
\hline$\frac{\mathscr{g}}{\frac{0}{2}}$ & 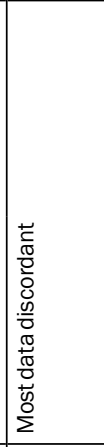 & 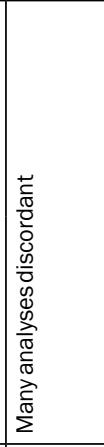 & 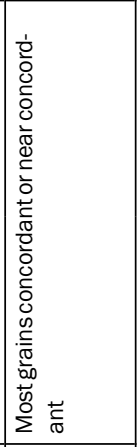 & 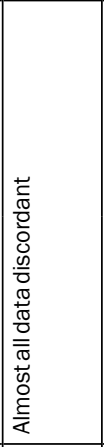 & 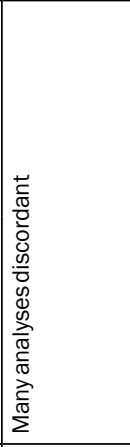 &  & 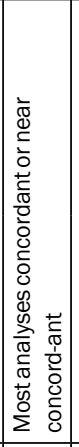 & 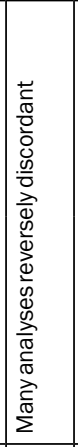 &  & 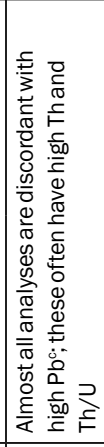 & 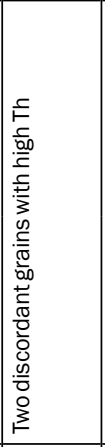 & 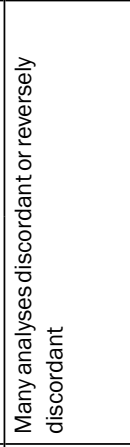 & 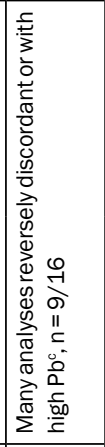 & 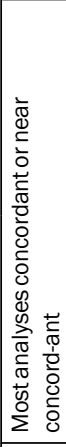 & 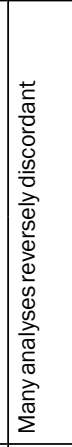 \\
\hline  & & & & & & & & 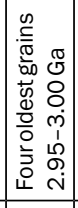 & & & 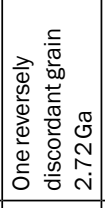 & & & 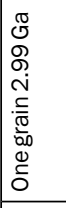 & \\
\hline 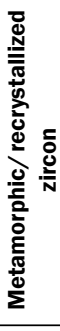 & & & 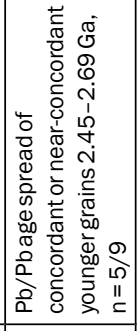 & & 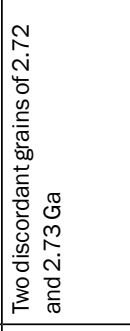 & 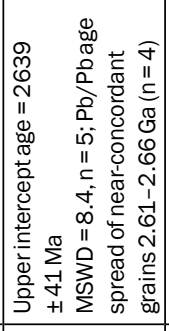 & 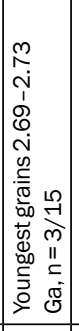 &  & & & 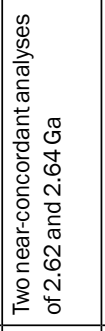 & &  & 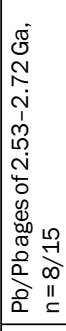 & 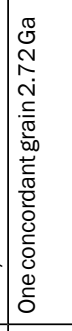 \\
\hline$\underset{8}{\stackrel{8}{8}}$ & 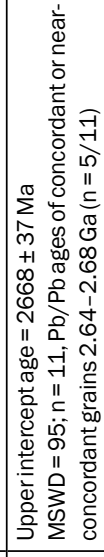 & 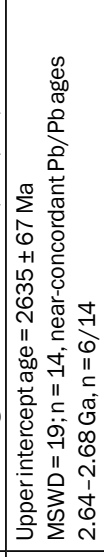 &  & 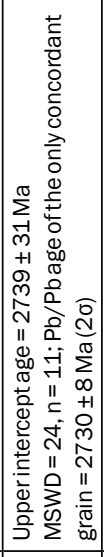 & 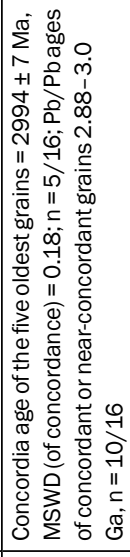 & &  & 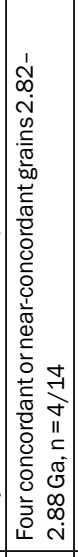 & 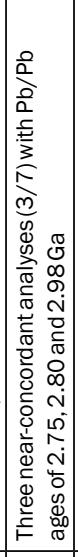 & 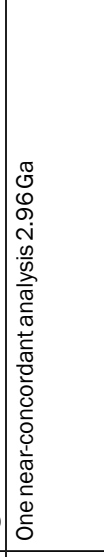 & 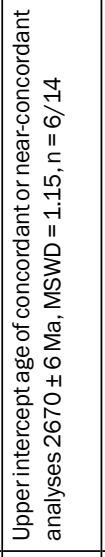 & 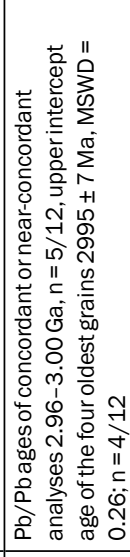 & 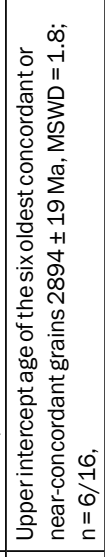 & 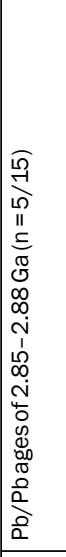 & 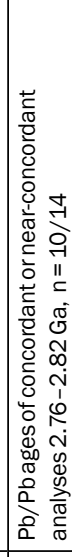 \\
\hline  & \begin{tabular}{|l}
$\overline{\underline{\varepsilon}}$ \\
$\bar{w}$ \\
$\underline{\underline{\underline{g}}}$ \\
\end{tabular} & \begin{tabular}{|l}
$\dot{\underline{\varepsilon}}$ \\
$\bar{w}$ \\
$\underline{\underline{\underline{\rho}}}$ \\
\end{tabular} & 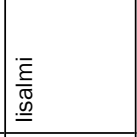 & \begin{tabular}{|l|}
$\underline{\underline{\varepsilon}}$ \\
$\underline{\underline{w}}$ \\
$\underline{\underline{\underline{o}}}$ \\
\end{tabular} & \begin{tabular}{|l}
$\bar{\varepsilon}$ \\
$\bar{\sigma}$ \\
$\underline{\underline{\underline{m}}}$ \\
\end{tabular} & $1 \frac{1}{\sigma 0}$ & 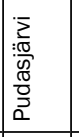 & 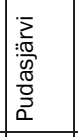 & 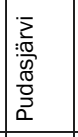 & 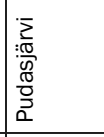 & $\sum_{\substack{: \\
0 \\
0 \\
0}}^{\infty}$ & 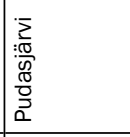 & 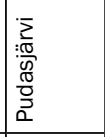 & \begin{tabular}{|l}
$\bar{\varepsilon}$ \\
$\underline{\underline{\sigma}}$ \\
$\underline{\underline{\underline{0}}}$ \\
\end{tabular} & \begin{tabular}{|l}
$\overline{\bar{\varepsilon}}$ \\
$\overline{\underline{\sigma}}$ \\
$\underline{\underline{\underline{g}}}$ \\
\end{tabular} \\
\hline 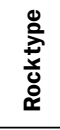 & 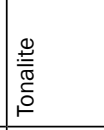 & 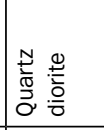 & 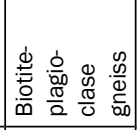 & 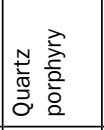 & 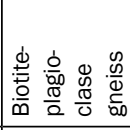 & 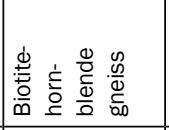 & 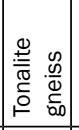 &  & 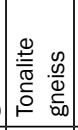 & 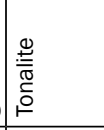 & 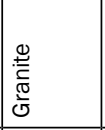 & 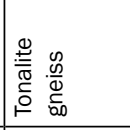 &  & 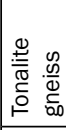 & 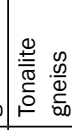 \\
\hline 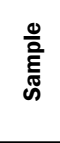 &  & 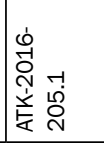 & 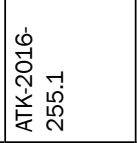 & 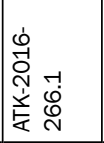 & 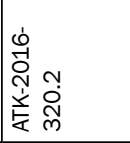 & 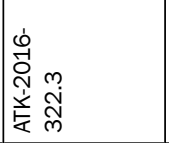 & 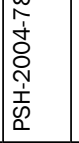 & 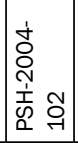 & 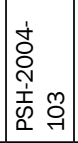 & 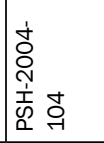 & 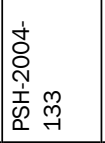 & 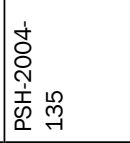 & 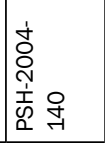 & 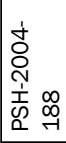 & 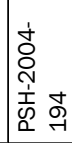 \\
\hline
\end{tabular}


A total of 19 spots were dated (Fig. 6a and Electronic Appendix D). One data point was ignored due to a high proportion of common lead. The U contents were moderate and generally $100-300 \mathrm{ppm}$. The U-Pb analyses on zoned zircon domains yielded both concordant and discordant data, with a spread of ${ }^{207} \mathrm{~Pb} /{ }^{206} \mathrm{~Pb}$ ages from 2.62 $2.70 \mathrm{Ga}$. For the most concordant and oldest dates, a concordia age of $2696 \pm 4 \mathrm{Ma}$ could be calculated, although with a quite high MSWD of $3.4(\mathrm{n}=7$, Fig. 6a). Three analyses on the structurally homogeneous rim and tip domains yielded ${ }^{207} \mathrm{~Pb} /{ }^{206} \mathrm{~Pb}$ ages of $2.62-2.65 \mathrm{Ga}$ (Fig. $5 \mathrm{a}-\mathrm{b}$ ). The $\mathrm{Th} / \mathrm{U}$ ratios of these domains $(0.47-0.54)$ are of the same order as the $\mathrm{Th} / \mathrm{U}$ ratios in other analysis spots (0.25-0.87, Fig. 7 and Electronic Appendix D).

A1959. The trondhjemitic gneiss A1959 yielded a small amount of zircon in the $>3.6 \mathrm{~g} \mathrm{~cm}^{-3}$ density fraction. The zircon population is fairly homogeneous with transparent to translucent, pale coloured, long prismatic zircon crystals with a variable grain size (c. 100-300 $\mu \mathrm{m})$. In addition, there are a few more equidimensional, usually larger grains and only some grains are turbid/ metamict. In the BSE images, the zircon appears more heterogeneous. In general, the thin and long zoned zircon is mostly without cores and rims (Fig. 5c-e). The stubby grains often show weakly zoned cores and thin zoned rims. Many zircon grains are fractured and altered, the others being fairly pristine.

A total of 29 zircon domains were dated (Electronic Appendix D). With a couple of exceptions, the ${ }^{207} \mathrm{~Pb} /{ }^{206} \mathrm{~Pb}$ ages of concordant analyses show a continuous spread from 2.71$2.90 \mathrm{Ga}$ (Fig. 6b). In the ${ }^{207} \mathrm{~Pb} /{ }^{206} \mathrm{~Pb}$ age histogram (Fig. 6b), there are two obvious frequency peaks at $2.74-2.75 \mathrm{Ga}$ and $2.89 \mathrm{Ga}$. One of the oldest cores $(10 \mathrm{a} / 2.90 \mathrm{Ga}$, Electronic Appendix D) is surrounded by a texturally zoned rim with an age of $2.73 \mathrm{Ga}$ (Fig. 5d). The dates of 2.74-2.75 Ga are the most common. All the analysed zircon except one have $\mathrm{Th} / \mathrm{U}$ ratios ranging from 0.17 to 0.39 , typical of magmatic rocks (Fig. 7). Therefore, it is supposed that the 2.74-2.75 Ga ages from the zoned zircon domains provide the best estimates for the crystallization age of the trondhjemitic magma. Seven concordant analyses in this group determine the concordia age of $2742 \pm 7 \mathrm{Ma}$ (MSWD = 1.8). The seven oldest dates yielded a concordia age of $2883 \pm 5 \mathrm{Ma}(\mathrm{MSWD}=1.17)$. The three youngest ages comprise a $2.67 \mathrm{Ga}(24 \mathrm{~b})$ rim around a 2.81 Ga core (24a, Fig. 5e) and a $2.67 \mathrm{Ga}$ (06a) core with a $2.61 \mathrm{Ga}(06 \mathrm{~b})$ texturally homogeneous rim. The latter has a low $\mathrm{Th} / \mathrm{U}$ ratio of 0.07 , but $24 \mathrm{~b}$ has a higher Th/U ratio (0.19) than the core (24a, 0.07, Fig. 7 and Electronic Appendix D). The youngest rims as well as the low- $\mathrm{U}, 2.67 \mathrm{Ga}$ core were presumably crystallized during the $2.60-2.70 \mathrm{Ga}$ metamorphism.

\subsubsection{LA-ICP-MS analyses from thin sections}

Of the six analysed samples from the neighbourhood of the $3.40 \mathrm{Ga}$ Rasvamäki gneiss (ATK2016 samples), only one sample, the biotiteplagioclase gneiss ATK-2016-320.2, yielded 2.99 Ga zircon crystals, whilst they are younger in other thin sections. In the biotite-plagioclase gneiss ATK-2016-255.1, ages spread from 2.45-2.85 Ga, and the quartz porphyry ATK-2016-266.1 was dated at $2.73 \mathrm{Ga}$, while in the other samples the ages were 2.64-2.67 Ga.

The calculated $\mathrm{Th} / \mathrm{U}$ ratios were relatively high, being $>0.30$ in almost all ATK-2016 specimens, suggesting that in most cases even the youngest, $<2.70 \mathrm{Ga}$ zircons were magmatic rather than metamorphic. This is also indicated by the oscillatory zoning of most grains, typical for magmatic zircon. The most discordant grains (\% of concordance $=38-72)$ in sample ATK-2016-205.1 are Th-rich, which results in very high $\mathrm{Th} / \mathrm{U}$ ratios. In sample PSH-2004-104, almost all analysed zircon grains are discordant (\% of concordance = 33-83), also having relatively high $\mathrm{Th} / \mathrm{U}$ ratios (Electronic Appendix H). 
Figure 6.

Concordia diagrams with the ${ }^{207} \mathrm{~Pb} /{ }^{206} \mathrm{~Pb}$ ages for the zircon analysed with the Nordic Cameca IMS 1270. Datapoint error ellipses and box heights in the insets are $2 \sigma$ in all figures.
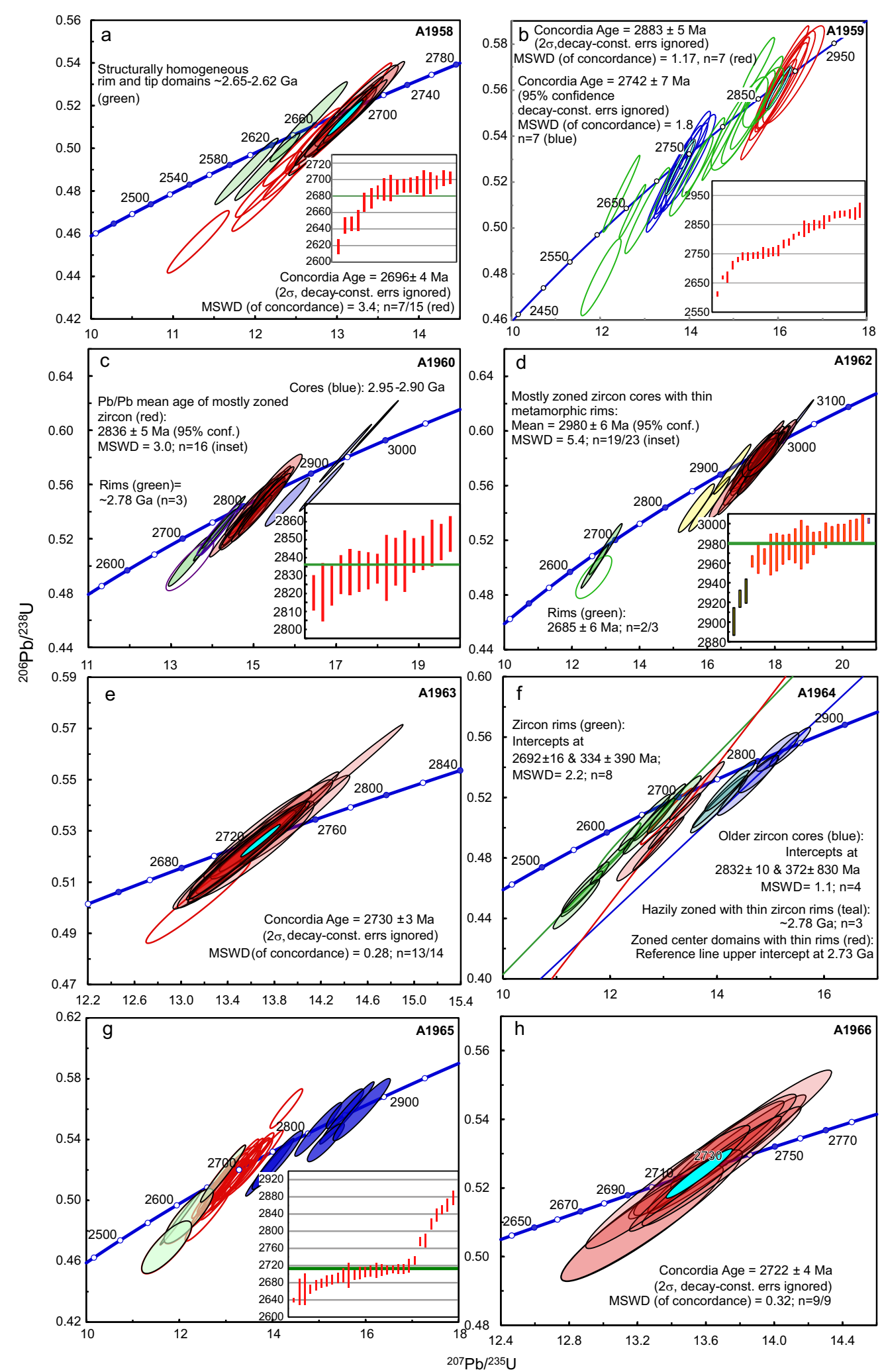


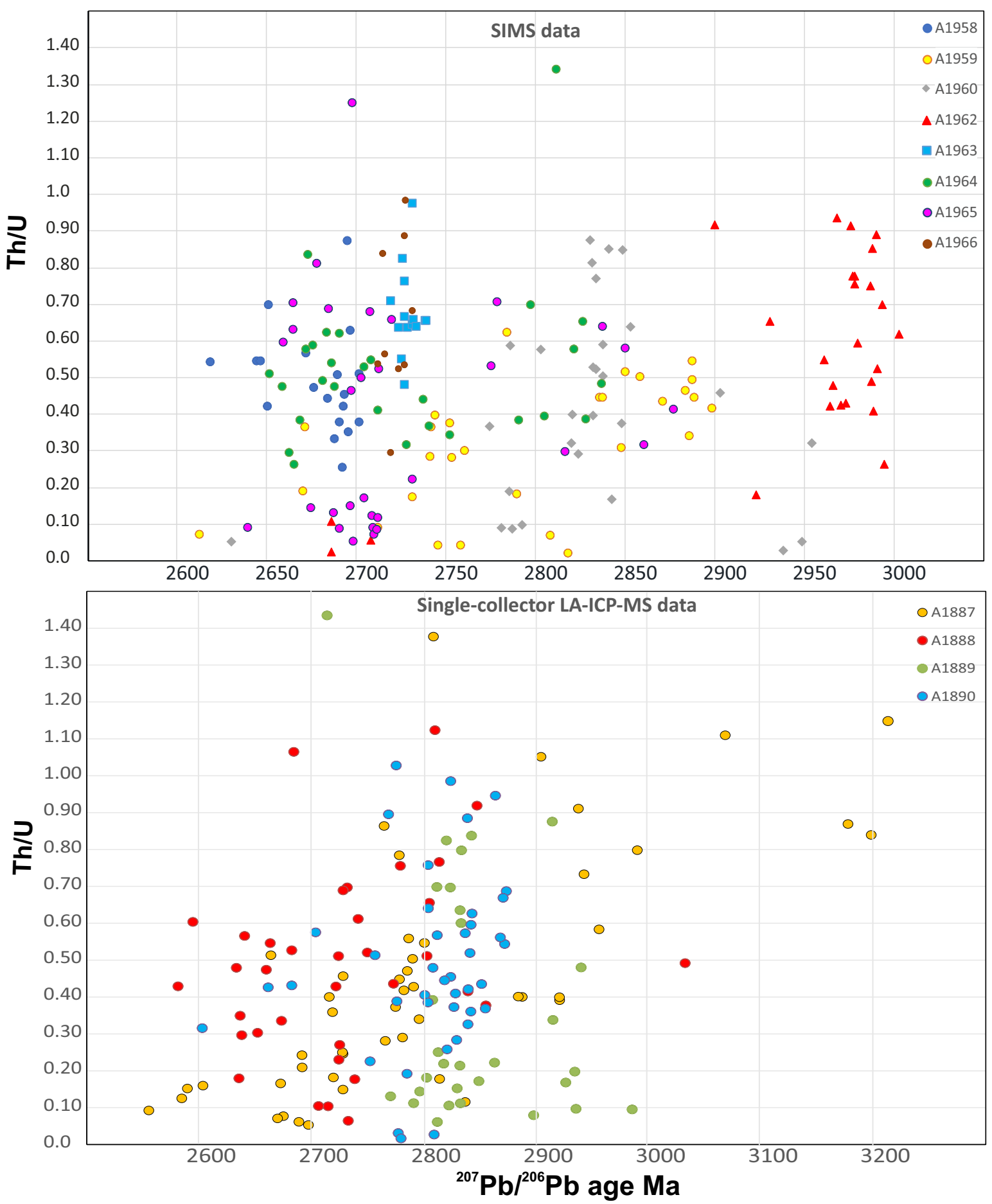

Figure 7. Measured Th/U ratios vs. the ${ }^{207} \mathrm{~Pb} /{ }^{206} \mathrm{~Pb}$ age of the separated zircon grains analysed using SIMS (upper figure) and calculated Th/U ratios yielded by single-collector LA-ICP-MS. 


\subsection{Suomussalmi}

A1960. The tonalite A1960 from the Suomussalmi area yielded abundant zircon in the density fraction of $>4.0 \mathrm{~g} \mathrm{~cm}^{-3}$. The population, consisting of dark brown, euhedral prismatic and transparent to turbid zircon, appears visually quite homogeneous. The grain size varies from ca. 50-500 $\mu \mathrm{m}$. In the BSE images, the zircon shows zoning and texturally homogeneous and pale cores. Some zircon grains displaying alteration are fractured, while the others appear fairly pristine (Fig. $5 \mathrm{f}-\mathrm{h}$ ).

A total of 28 zircon domains were dated using SIMS (Fig. 6c and Electronic Appendix D). The $\mathrm{U}$ concentrations are mostly low, but very high values were measured on texturally homogeneous cores. Both the old cores and younger rims show the lowest Th/U ratio (0.03-0.05, Figure 7). There were only a few zircon crystals with such low $\mathrm{Th} / \mathrm{U}$ ratios, and in most grains the $\mathrm{Th} / \mathrm{U}$ ratio is 0.10 0.87 . The oldest ${ }^{207} \mathrm{~Pb} /{ }^{206} \mathrm{~Pb}$ ages of $2.94-2.95 \mathrm{Ga}$ were measured from texturally homogeneous cores (Fig. $5 \mathrm{f}-\mathrm{g}$ ). On the concordia line, most of the $\mathrm{U}-\mathrm{Pb}$ data plot at $2.80-2.85 \mathrm{Ga}$. The age of $2836 \pm 5 \mathrm{Ma}$ is determined by the mean ${ }^{207} \mathrm{~Pb} /{ }^{206} \mathrm{~Pb}$ ages of the zoned zircon grains. Six zircon grains yielded younger ages of 2.78-2.79 Ga (Fig. 5g-h). This result is ambiguous and could either mean that the magma crystallized at $2.84 \mathrm{Ga}$, the younger dates representing $\mathrm{Pb}$ loss during the 2.60-2.70 Ga metamorphism, or that the crystallization took place at ca. $2.78 \mathrm{Ga}$, the older zircon being inherited.

A1962. The trondhjemite sample A1962 from Suomussalmi yielded a small amount of zircon in the $>4.0 \mathrm{~g} \mathrm{~cm}^{-3}$ density fraction. It is mostly long prismatic, brown and translucent to turbid, with a grain size of c. 50-400 $\mu \mathrm{m}$. In the BSE images, zircon appears fairly homogeneous, generally fractured and weakly zoned. Some grains have a weakly zoned inner domain with an unzoned or weakly zoned rim (Fig. 5i-j).

Sample A1962 was taken from the same outcrop as sample A1909 in Mikkola et al. (2011), whose TIMS analyses did not yield any meaningful age. However, based on the ${ }^{207} \mathrm{~Pb} /{ }^{206} \mathrm{~Pb}$ ratios, they concluded that the average age of zircon must be more than $2.92 \mathrm{Ga}$. In the present study, a total of 26 zircon domains were dated (Fig. 6d and Electronic Appendix D). They have varying U contents and a Th/U ratio of $0.18-0.93$. The three lowest $\mathrm{Th} / \mathrm{U}$ ratios $(0.02,0.06,0.11)$ were measured from the young zircon rims with an approximate age of $2.69 \mathrm{Ga}$ (Fig. 7), recording metamorphism. On the concordia diagram, most of the $\mathrm{U}-\mathrm{Pb}$ data plot at $2.95-3.0 \mathrm{Ga}$, with a mean ${ }^{207} \mathrm{~Pb} /{ }^{206} \mathrm{~Pb}$ age of $2980 \pm 6 \mathrm{Ma}$. Because the three meaningfully younger data points at $2.90-2.93 \mathrm{Ga}$ were measured from zoned zircon domains, they may also represent $\mathrm{Pb}$ loss caused by the $2.60-2.70 \mathrm{Ga}$ metamorphism. The oldest measured ${ }^{207} \mathrm{~Pb} /{ }^{206} \mathrm{~Pb}$ age was $3003 \pm 2 \mathrm{Ma}$ (Fig. 5j).

\subsection{Ilomantsi}

A1963. The sanukitoid sample A1963 from the Ilomantsi area yielded a large amount of pale, rather homogeneous zircon. In the density fraction of $>4.2 \mathrm{~g} \mathrm{~cm}^{-3}$, the zircon is fairly short $(100-200 \mu \mathrm{m})$ and stubby, mainly fine to medium-grained and translucent. The finer grains are transparent. The fraction $3.6-4.2 \mathrm{~g} \mathrm{~cm}^{-3}$ contains a small quantity of longer prismatic grains. In the BSE images, the zircon principally consists of pristine, oscillatory zoned grains (Fig. 5k-l). Zircon has many small inclusions that are presumably apatite.

A total of 14 zircon domains were dated using SIMS (Fig. 6e and Electronic Appendix D). The $\mathrm{U}$ concentrations and $\mathrm{Th} / \mathrm{U}$ ratios are generally $100-200$ ppm and $0.48-0.97$, respectively. All the measured $\mathrm{U}-\mathrm{Pb}$ data plot in a tight cluster. Thirteen of the 14 analyses provided a concordia age of $2730 \pm 3 \mathrm{Ma}(\mathrm{MSWD}=0.28)$.

A1964. The sanukitoid sample A1964 contained abundant zircon in the $>4.2 \mathrm{~g} \mathrm{~cm}^{-3}$ density fraction. It is either prismatic $(\mathrm{l}: \mathrm{w} \geq 2.5)$, euhedral or subhedral, brown or reddish (altered/ metamict) to colourless, transparent to translucent, with a variable grain size (ca. 50-300 $\mu \mathrm{m})$. In the BSE images, the zircon crystals are commonly oscillatory zoned (Fig. $5 \mathrm{~m}-\mathrm{n}$ ). Some grains with 
zoned cores have structurally rather homogeneous, weakly zoned rims. Some grains are strongly fractured.

A total of 30 zircon domains were dated (Fig. $6 f$ and Electronic Appendix D). Nine analyses were rejected due to a high common $\mathrm{Pb}$ proportion and/ or a high degree of discordance. The $\mathrm{U}-\mathrm{Pb}$ data fall into four apparent age groups. The analyses on four older zircon cores/centre domains gave an upper intercept age of $2832 \pm 10 \mathrm{Ma}$ (MSWD $=1.1)$. Three $\mathrm{U}-\mathrm{Pb}$ data points are approximately coeval at $-2.78 \mathrm{Ga}$ and five zoned centre domains/ cores plot approximately on the same reference line, intercepting the concordia curve at $-2.73 \mathrm{Ga}$. The youngest zircon domains yielded an upper intercept age of $2692 \pm 16 \mathrm{Ma}(\mathrm{MSWD}=2.2, \mathrm{n}=8)$. These analyses were from texturally fairly homogeneous rim domains; some centre domains also yielded the same age (Fig. $5 \mathrm{~m}-\mathrm{n}$ ). The $\mathrm{Th} / \mathrm{U}$ ratios in the youngest grains or domains do not differ from those in the older ones (0.3-0.8 in both groups, 2.7 in one 2.70 Ga rim domain, Electronic Appendix D), suggesting that they are not metamorphic. Therefore, it is presumable that the crystallization of the magma took place at around $2.69 \mathrm{Ga}$ and the older grains and cores are inherited.

\subsection{Pudasjärvi}

\subsubsection{SIMS analyses}

A1965. The trondhjemite sample A1965 from the Pudasjärvi area yielded a very small amount of zircon in the $>3.6 \mathrm{~g} \mathrm{~cm}^{-3}$ density fraction. The population mostly consisted of fine-grained (50-200 $\mu \mathrm{m})$, long/thin prismatic, and transparent to translucent zircon. A few subhedral, elongated, larger $(300-400 \mu \mathrm{m})$ grains were also found. In the BSE images, the narrow zircon prisms show oscillatory zoning. The more stubby grains often show cores with moderate to weak zoning and thin weakly zoned rims (Fig. 5o-p).

A total of 31 zircon domains were dated (Fig. $6 \mathrm{~g}$ and Electronic Appendix D). On the concordia diagram, the U-Pb ages scatter between $2.66 \mathrm{Ga}$ and $2.88 \mathrm{Ga}$. The supposedly inherited zircon grains and cores have ages of $2.82-2.88 \mathrm{Ga}$ (Fig. 5o-p) and $2.78 \mathrm{Ga}$. The rest of the data show a continuous spread of ${ }^{207} \mathrm{~Pb} /{ }^{206} \mathrm{~Pb}$ ages from 2.73-2.64 Ga. Most of the zoned zircon domains/grains are $-2.70 \mathrm{Ga}$, the mean of the ${ }^{207} \mathrm{~Pb} /{ }^{206} \mathrm{~Pb}$ ages of these analyses being $2706 \pm$ $4 \mathrm{Ma}(\mathrm{MSWD}=1.5, \mathrm{n}=15)$. The $\mathrm{U}$ concentrations and $\mathrm{Th} / \mathrm{U}$ ratios vary, but they are mainly rather low to moderate. Those zircon domains whose age is $\leq 2.73 \mathrm{Ga}$, including the youngest ones, have both low (0.05-0.22) and moderate (0.45-1.25) Th/U ratios (Fig. 7). Presumably, the crystallization age of the trondhjemite was ca. $2.70 \mathrm{Ga}$, with the younger domains and grains of 2.66-2.69 Ga representing metamorphism.

A1966. Zircon in the trondhjemite A1966 from the Pudasjärvi area is mostly colourless and transparent, either short to long prismatic or subhedral, and oval shaped. The grain size varies, but zircon is predominantly fine-grained (100-200 $\mu \mathrm{m})$. Overall, although there are differences in zircon morphologies, the grains appear fairly homogeneous. In the BSE images, the population also shows extreme homogeneity, consisting of pristine oscillatory zoned zircon (Fig. 5q-r).

A total of 9 zircon domains were dated (Fig. 6 h and Electronic Appendix D). The rather low-U zircon grains yielded a univocal age of $2722 \pm 4 \mathrm{Ma}$ $(\mathrm{MSWD}=0.32, \mathrm{n}=9)$ for the trondhjemite. The $\mathrm{Th} / \mathrm{U}$ ratios are relatively high, $0.30-0.98$ (Fig. 7), suggesting that all zircon grains are magmatic.

\subsubsection{LA-ICP-MS analyses from thin sections}

None of the seven samples collected in the vicinity of the $3.50 \mathrm{Ga}$ Siurua gneiss in Pudasjärvi yielded ages older than 3.0 Ga. However, in most thin sections there were zircon grains of 2.90-3.00 Ga. This was also the case in the two samples from the Iisalmi area, where the oldest grains were 2.90-2.93 Ga. Many samples have grains of 2.64-2.73 Ga or even younger. Apart from the 
granite PSH \$-2004-133, these often have a low $\mathrm{Th} / \mathrm{U}$ ratio (Electronic Appendix $\mathrm{H}$ ), suggesting a metamorphic origin. Because of the small size of many of the analysed zircons, the relatively large beam width of $20 \mu \mathrm{m}$ and the depth of the pit $(-30 \mu \mathrm{m})$, some results may represent mixed ages if the grains had zones of various ages.

\subsection{Taivalkoski}

\subsubsection{TIMS analyses}

A1887. The granite sample A1887 yielded abundant euhedral zircon (c. 50-300 $\mu \mathrm{m}$ ), which is rounded on crystal edges by resorption, light coloured and turbid, and accordingly has a low density. The BSE images display only weak zoning (Electronic Appendix G).

All four zircon fractions analysed using TIMS are U-rich, discordant and have similar $\mathrm{Pb} / \mathrm{U}$ ratios. TIMS analyses provided a minimum age of ca. 2.6 Ga, the ${ }^{207} \mathrm{~Pb} /{ }^{206} \mathrm{~Pb}$ ages being $2.61-2.62 \mathrm{Ga}$ (Electronic Appendix E). An attempt to use the CA-TIMS technique failed. The analytical data presented here from the TIMS analyses are provided in Electronic Appendix E.

A1888. The mineral separation of tonalite A1888 produced only a small amount of zircon, which is heterogeneous in size (c. $100-300 \mu \mathrm{m})$ and morphology. Both long prismatic and rounded stubby grains were found. Both types often show weak or strong zoning in BSE images. Some large grains have a weakly zoned centre and a rim that looks like an overgrowth (Electronic Appendix G). Because of the small amount of separated zircon, TIMS analyses were not performed on this sample.

A1889. Abundant dark euhedral zircon was obtained from the A1889 tonalite sample. The grains are long prisms (ca. 100-200 $\mu \mathrm{m}$ ) or oval shaped with faint zoning. Some grains appear to have a distinct strongly zoned core with a weakly zoned overgrowth rim (zr 15, Electronic Appendix $\mathrm{G).}$

The TIMS analyses are discordant and slightly scattered and give intercepts with the concordia at
$745 \pm 530$ and $2803 \pm 25 \mathrm{Ma}(\mathrm{MSWD}=7.3)$. In contrast, the CA-TIMS analysis (F, Electronic Appendix $\mathrm{E}$ ) is concordant and very low in common $\mathrm{Pb} \quad\left({ }^{206} \mathrm{~Pb} /{ }^{204} \mathrm{~Pb} \approx 100000\right)$, and including this, the intercepts are $607 \pm 330$ and $2796 \pm 12 \mathrm{Ma}$ (MSWD = 10.4, Electronic Appendix E).

A1980. Zircon obtained from the A1890 trondhjemite sample comprised euhedral dark grains. All are long (c. 100-300 $\mu \mathrm{m}$ ), prismatic and weakly zoned (Electronic Appendix G).

The conventional $\mathrm{U}-\mathrm{Pb}$ analyses revealed that common $\mathrm{Pb}$ is low, but the data are heterogeneous and slightly discordant, providing ${ }^{207} \mathrm{~Pb} /{ }^{206} \mathrm{~Pb}$ ages of 2.85-2.90 Ga. One analysis, using pretreatment according to Mattinson (2005), instead yielded a concordant result of $2826 \pm 7 \mathrm{Ma}$ (analysis $\mathrm{F}$ in Electronic Appendix E). The Th/U ratio (inferred from radiogenic ${ }^{208} \mathrm{~Pb} /{ }^{206} \mathrm{~Pb}$ ) is higher than in the other analyses, pointing to a magmatic rather than a metamorphic origin.

\subsubsection{LA-ICP-MS analyses}

A1887. Single-collector LA-ICP-MS analyses yielded a large age spread, the oldest nearconcordant grains being 3.1-3.2 Ga and several grains between 2.88-2.96 Ga (Fig. 8a). The other analysed grains fall into two groups, the older group yielding an almost continuous spread of ${ }^{207} \mathrm{~Pb} /{ }^{206} \mathrm{~Pb}$ ages from $2.77-2.84 \mathrm{Ga}$, and the younger group yielding ages of 2.66-2.73 Ga. Two of the analysed 3.1-3.2 Ga grains have overgrowth rims of 2.72 Ga and 2.69 Ga (grains 27 and 33, Electronic Appendices $F$ and $G$ ). In both of these, the rim has a lower $\mathrm{Th} / \mathrm{U}$ ratio than the core (core 0.84 , rim 0.18 and core 1.11, rim 0.06, respectively; Electronic Appendix F). Homogeneous irregular-shaped large grain 10 has an inner domain of $2.79 \mathrm{Ga}$ and an outer domain of $2.67 \mathrm{Ga}$. Grains 13 and 17 have inner domains of 2.72 and $2.73 \mathrm{Ga}$, respectively, and rims of 2.59 and $2.68 \mathrm{Ga}$. In addition, one 2.90 Ga grain (26) has a rim of $2.58 \mathrm{Ga}$.

Most multicollector analyses yielded an age of $2.70 \mathrm{Ga}$. Of these, concordant or near-concordant analyses provided a concordia age of $2702 \pm 11 \mathrm{Ma}$ 
$(2 \sigma$, MSWD of concordance $=0.043, \mathrm{n}=15)$. There were three analyses of 2.60-2.61 Ga but no grains older than ca. $2.70 \mathrm{Ga}$ (Fig. 8b). This may result from the smaller number of analyses compared with single-collector data. Also, the multicollector analyses were mostly performed on large prismatic, $>200 \mu \mathrm{m}$ oscillatory zoned grains (Electronic Appendix E), whereas other zircon morphologies were also analysed with single-collector LA-ICP-MS.

The abundance of grains dated at around 2.70 Ga suggests that this was the crystallization age of the magma, the older grains being inherited.

A1888. Single-collector LA-ICP-MS analyses yielded an almost continuous spread of concordant or near-concordant ${ }^{207} \mathrm{~Pb} /{ }^{206} \mathrm{~Pb}$ ages $(\mathrm{n}=29)$ from 2.63-2.81 Ga (Fig. 8c). One concordant rim analysis (11b, Electronic Appendix F) yielded a $2.59 \mathrm{Ga}$ age and one grain (27, Electronic Appendix F) has a $2.85 \mathrm{Ga}$ core and a $2.64 \mathrm{Ga}$ rim. Grain 28 has a core of $2.80 \mathrm{Ga}$ and a rim of $2.72 \mathrm{Ga}$. One irregular-shaped structureless grain yielded a ${ }^{207} \mathrm{~Pb} /{ }^{206} \mathrm{~Pb}$ age of $3.0 \mathrm{Ga}$. Apart from one analysis (09, Electronic Appendix F), all the $\mathrm{Th} / \mathrm{U}$ ratios cluster from 0.10 to 1.10 (Fig. 7 ), pointing to a magmatic origin for zircon.

The multicollector data also display a similar spread of concordant ${ }^{207} \mathrm{~Pb} /{ }^{206} \mathrm{~Pb}$ ages $(\mathrm{n}=26)$ from 2.65-2.81 Ga, five analyses yielding ages of 2.90$2.95 \mathrm{Ga}$ and four analyses yielding ages of 3.10$3.20 \mathrm{Ga}$ (Fig. 8d). The high abundance of grains dated at 2.70-2.74 indicates that the crystallization of the tonalitic melt took place at this time.

A1889. Single-collector LA-ICP-MS analyses $(\mathrm{n}=29)$ yielded two age groups. In the older group, the ${ }^{207} \mathrm{~Pb} /{ }^{206} \mathrm{~Pb}$ ages were $2.90-2.99 \mathrm{Ga}$, while the younger group showed a spread of concordant ages from 2.77-2.86 Ga (Fig. 8e). Grain 11 had a core of $2.99 \mathrm{Ga}$ and a rim of $2.77 \mathrm{Ga}$, and in grain 15 , the core yielded an age of $2.94 \mathrm{Ga}$ and the rim $2.81 \mathrm{Ga}$ (Electronic Appendix F). Apart from a few analyses, the $\mathrm{Th} / \mathrm{U}$ ratios are $0.10-0.88$. This ratio does not depend on the age (Fig. 7), the lowest ratios of ca. 0.1 being found in both the youngest and the oldest grains.
In the multicollector data $(\mathrm{n}=18)$, most analysed spots yielded ${ }^{207} \mathrm{~Pb} /{ }^{206} \mathrm{~Pb}$ ages of 2.82 $2.86 \mathrm{Ga}$. Six analyses yielded a spread of ages from 2.78-2.71 Ga (Fig. 7f). One grain with an inner domain of $2.84 \mathrm{Ga}$ had a rim yielding an age of $2.78 \mathrm{Ga}$ (8a and 8b, Electronic Appendix E).

Most analyses in the LA-ICP-MS data yielded ages of $2.80-2.86 \mathrm{Ga}$, which suggests that the crystallization of the tonalite magma took place within this age bracket.

A1890. Single-collector LA-ICP-MS analyses $(\mathrm{n}=35)$ yielded a continuous spread of concordant ${ }^{207} \mathrm{~Pb} /{ }^{206} \mathrm{~Pb}$ ages from $2.77-2.87 \mathrm{Ga}$ (Fig. 8g). Four younger analyses with ages from $2.60-2.75 \mathrm{Ga}$ were from overgrowth rims. The grain 09 had an inner domain of $2.78 \mathrm{Ga}$ with an overgrowth rim of $2.68 \mathrm{Ga}$. In the grain 17 the inner domain $(17 \mathrm{a}$, Electronic Appendix F) yielded an age of $2.84 \mathrm{Ga}$ and the outer domain (17b) was dated at $2.78 \mathrm{Ga}$. In the grain 18 , the ${ }^{207} \mathrm{~Pb} /{ }^{206} \mathrm{~Pb}$ age of the core was $2.82 \mathrm{Ga}(18 \mathrm{a})$ and that of the rim $2.75 \mathrm{Ga}(18 \mathrm{~b}$, Electronic Appendices F and G). The Th/U ratios are mostly between $0.25-0.90$. In grain 17 , the inner domain yielded a Th/U ratio of 0.83 and the outer domain 0.02. Multicollector analyses $(n=29)$ reveal a similar ${ }^{207} \mathrm{~Pb} /{ }^{206} \mathrm{~Pb}$ age spread from 2.75 $2.85 \mathrm{Ga}$, but also two grains of 3.10-3.20 Ga and four grains of 2.92-2.94 Ga (Fig. 8h).

Most analyses in the LA-ICP-MS data yielded ages of 2.80-2.84 Ga, which are interpreted as the time span for the crystallization of the trondhjemite magma. The younger analyses presumably represent metamorphism and the $>2.90 \mathrm{Ga}$ ages represent inherited grains.

\subsection{Sm-Nd analyses}

The results of the Sm-Nd analyses and the analytical data are presented in Table 2. The data indicate differences in $\varepsilon_{N d}(t)$ and model ages. The youngest, 2.69-2.74 Ga granitoids from the Pudasjärvi and Iisalmi areas have $\varepsilon_{N d}(t)$ values of +1.1 to +2.2 , close to the depleted mantle values, with model ages $\left(\mathrm{t}_{\mathrm{DM}}\right)$ of 2.71-2.79 Ga. Sample A1965 has a high epsilon, 


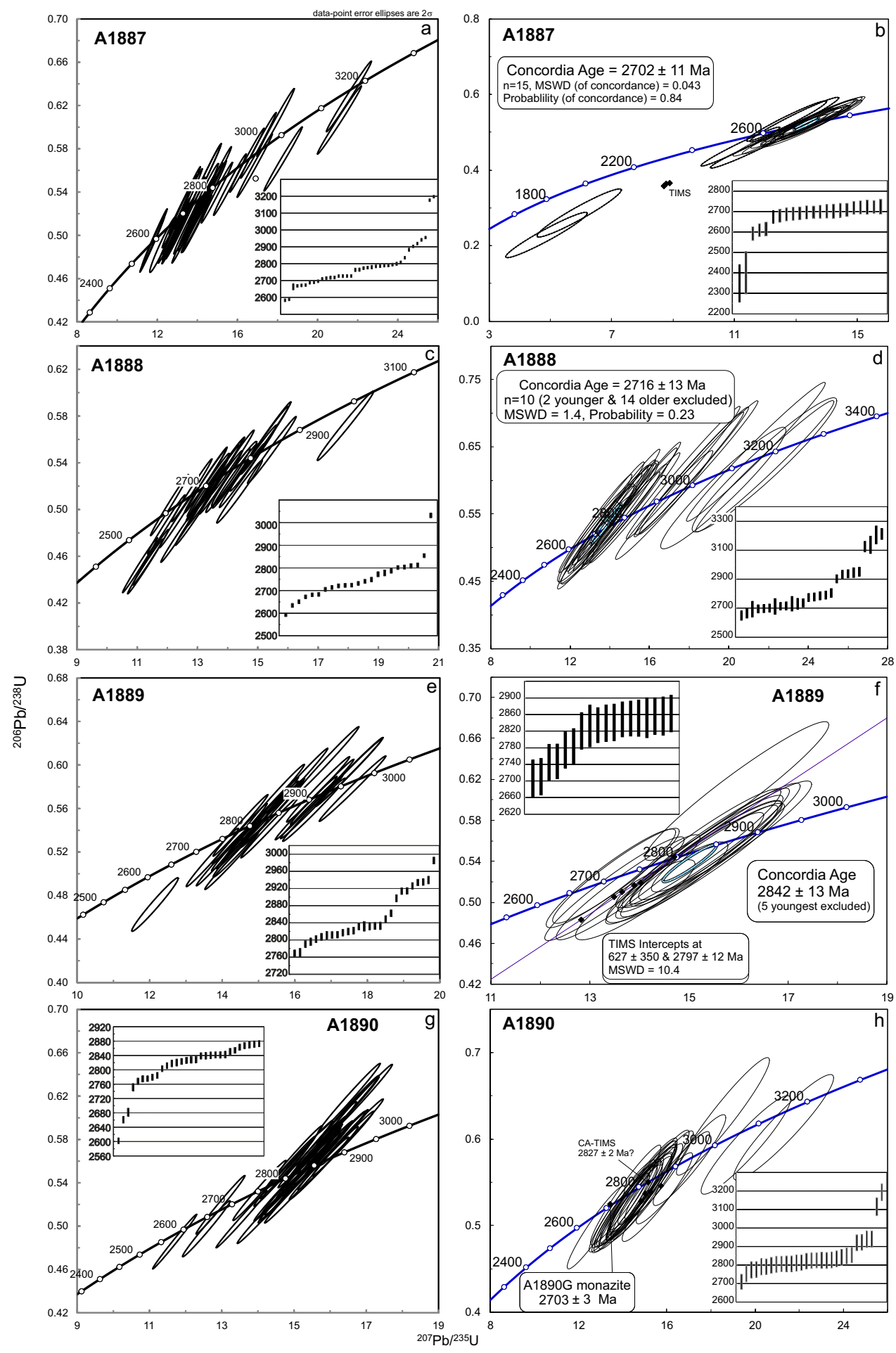

Figure 8. Concordia diagrams with the ${ }^{207} \mathrm{~Pb} /{ }^{206} \mathrm{~Pb}$ ages for LA-ICP-MS data from separated zircon grains from the Taivalkoski area. a), c), e) and g) were analysed using single-collector equipment; b), d), f) and g) were analysed using multicollector LA-ICP-MS. Data-point error ellipses and box heights in the insets are $2 \sigma$ in all figures. 
Table 2. Table 2. Sm-Nd analytical data.

\begin{tabular}{|c|c|c|c|c|c|c|c|c|c|c|c|}
\hline Sample & Area & Rock type & $\begin{array}{c}\text { Sm } \\
(\mathbf{p p m})\end{array}$ & $\begin{array}{c}\text { Nd } \\
(\mathbf{p p m})\end{array}$ & ${ }^{147} \mathrm{Sm} /{ }^{144} \mathrm{Nd}$ & $\pm 0.4 \%$ & ${ }^{143} \mathrm{Nd} /{ }^{144} \mathrm{Nd}$ & $2 \sigma e$ & $\mathbf{t}(\mathbf{M a})$ & eps(t) & $\begin{array}{c}\text { t-DM } \\
\text { De Paolo }\end{array}$ \\
\hline A1958 & lisalmi & Tonalite & 8.10 & 52.10 & 0.0940 & 0.0004 & 0.51087 & 0.00001 & 2696 & 1.1 & 2772 \\
\hline A1959 & lisalmi & Trondhjemite & 2.60 & 17.09 & 0.0920 & 0.0004 & 0.51082 & 0.00001 & 2742 & 1.4 & 2791 \\
\hline A1960 & Suomussalmi & Tonalite & 2.29 & 15.54 & 0.0892 & 0.0004 & 0.51065 & 0.00001 & 2836 & 0.4 & 2940 \\
\hline A1962 & Suomussalmi & Trondhjemite & 2.33 & 17.18 & 0.0818 & 0.0003 & 0.51036 & 0.00001 & 2980 & -0.4 & 3114 \\
\hline A1963 & Ilomantsi & Granite & 4.05 & 25.04 & 0.0977 & 0.0004 & 0.51087 & 0.00001 & 2730 & 0.2 & 2865 \\
\hline A1964 & Ilomantsi & Granite & 7.05 & 40.36 & 0.1056 & 0.0004 & 0.51100 & 0.00001 & 2728 & 0.0 & 2887 \\
\hline A1965 & Pudasjärvi & Trondhjemite & 5.57 & 36.94 & 0.0911 & 0.0004 & 0.51087 & 0.00001 & 2706 & 2.2 & 2710 \\
\hline A1966 & Pudasjärvi & Trondhjemite & 2.46 & 16.62 & 0.0893 & 0.0004 & 0.51081 & 0.00001 & 2722 & 2.0 & 2738 \\
\hline A1887 & Taivalkoski & Granite & 3.72 & 21.88 & 0.1028 & 0.0004 & 0.51087 & 0.00001 & 2700 & -2.0 & 3005 \\
\hline A1888 & Taivalkoski & Tonalite & 0.63 & 5.07 & 0.0752 & 0.0003 & 0.51039 & 0.00002 & 2700 & -1.8 & 2929 \\
\hline A1889 & Taivalkoski & Trondhjemite & 2.27 & 15.21 & 0.0903 & 0.0004 & 0.51067 & 0.00002 & 2800 & -0.1 & 2939 \\
\hline A1890 & Taivalkoski & Tonalite & 0.78 & 5.64 & 0.0835 & 0.0003 & 0.51043 & 0.00002 & 2800 & -2.3 & 3069 \\
\hline
\end{tabular}

Measurements were taken using a VG Sector 54 mass spectrometer.

The error in $147 \mathrm{Sm} / 144 \mathrm{Nd}$ is $0.4 \%$

The $143 \mathrm{Nd} / 144 \mathrm{Nd}$ ratio is normalized to $146 \mathrm{Nd} / 144 \mathrm{Nd}=0.7219$

Measurements of the La Jolla standard yielded a ratio of $0.511860 \pm 0.000010$ ( 2 standard error of mean).

$t(\mathrm{Ma})$ is the age of the rock yielded by the SIMS analyses (A1958-A1966) or the approximate age interpreted from the LA-ICP-MS analyses (A1887A1890).

$+2.2(2706 \mathrm{Ma})$, and a young model age $(2710 \mathrm{Ma})$, although it contains $2.8-2.9 \mathrm{Ga}$ inherited zircon. The high epsilon indicates that the abundance of inherited material is not, however, high. In samples from the Taivalkoski area, the epsilon ranges from -2.3 to -0.1 , the model ages being from 2.94 to $3.07 \mathrm{Ga}$. The Ilomantsi sanukitoids yielded an epsilon of 0.0 to +0.2 and model ages of 2.87$2.88 \mathrm{Ga}$. Tonalites from Suomussalmi had $\varepsilon_{\mathrm{Nd}}(\mathrm{t})$ values of -0.4 and +0.4 , with model ages of 3.11 and $2.94 \mathrm{Ga}$, respectively.

\section{Discussion}

\subsection{U-Pb and Nd data}

With a few exceptions, the previously dated TTGs in the Archean of Finland have yielded
Neoarchean, <2.84 Ga ages (Hölttä et al. 2012). However, most of those investigations were performed close to the greenstone belts, the other areas having been underexplored. In our SIMS and LA-ICP-MS data, most samples have at least a few relatively old, 2.90-3.00 Ga zircon grains or inherited cores, and in some specimens, most zircon grains are this old (Fig. 6). The samples from the Taivalkoski area contain even older, 3.103.20 Ga grains (Fig. 8). Inherited zircon cores with ${ }^{207} \mathrm{~Pb} /{ }^{206} \mathrm{~Pb}$ ages up to $3.2 \mathrm{Ga}$ were also observed by Heilimo et al. (2011) in the sanukitoids of the western Karelia Province. This indicates that the Neoarchean TTG magmas in most cases comprise older reworked or recycled material.

In most samples, the $\varepsilon_{\mathrm{Nd}}(\mathrm{t})$ value is either positive or only slightly negative, from -0.4 to +2.2 , militating in favour of their juvenile magmatic origin. Samples A1965 and A1966 from Pudasjärvi, 
dated at 2.71-2.72 Ga, yielded $\varepsilon_{\mathrm{Nd}}(\mathrm{t})$ values of around +2 , close to those of the depleted mantle $(\mathrm{DM})$ at $2.7 \mathrm{Ga}$. Of these two samples, A1966 also has a high $\mathrm{Na}_{2} \mathrm{O} / \mathrm{K}_{2} \mathrm{O}$ ratio (Fig. 4 and Electronic Appendix B), which is commonly interpreted to reflect the deep melting of the precursor (e.g. Moyen (2011)). In the large data set from Finland by Huhma et al. (2012), only a few TTGs show such high $\varepsilon_{\mathrm{Nd}}$ values. However, these high values are not restricted to the $<2.75 \mathrm{Ga}$ granitoids. In addition, two of the specimens with high initial $\varepsilon_{\mathrm{Nd}}$ (A1959) with $\varepsilon_{\mathrm{Nd}}$ of 1.4 and A1965 with $\varepsilon_{\mathrm{Nd}}$ of 2.2, Table
2) contain many zircon grains that are older than the model age of the rock (2791 Ma and $2710 \mathrm{Ma}$, respectively). This suggests that regardless of the high initial $\varepsilon_{\mathrm{Nd}}$ value, they must have assimilated some older crustal material.

Three samples from the Taivalkoski area yielded lower $\varepsilon_{\mathrm{Nd}}$ values from -1.8 to -2.3 , with model ages of 2.93-3.07 Ga. In the data by Huhma et al. (2012) and Mikkola et al. (2011), there are also quite a few samples with low epsilon values from -1 to -7 . Figure 9 illustrates the distribution of the $\mathrm{Nd}$ model ages of the Archean granitoids in eastern
Figure 9. Distribution of tDM model ages in the Archean granitoids of eastern Finland in the data by Huhma et al. (Huhma etal. 2012). Red dots: $t_{D M}>3.20-$ $3.80 \mathrm{Ga}$, Yellow dots: $\mathrm{t}_{\mathrm{DM}}$ = 3.00-3.20 Ga, green dots: $\mathrm{t}_{\mathrm{DM}}=2.90-3.00$ $\mathrm{Ga}$; blue dots: $\mathrm{t}_{\mathrm{DM}}<2.90$ $\mathrm{Ga}$. Model ages older than 3.50 are only found in the Siurua gneisses.

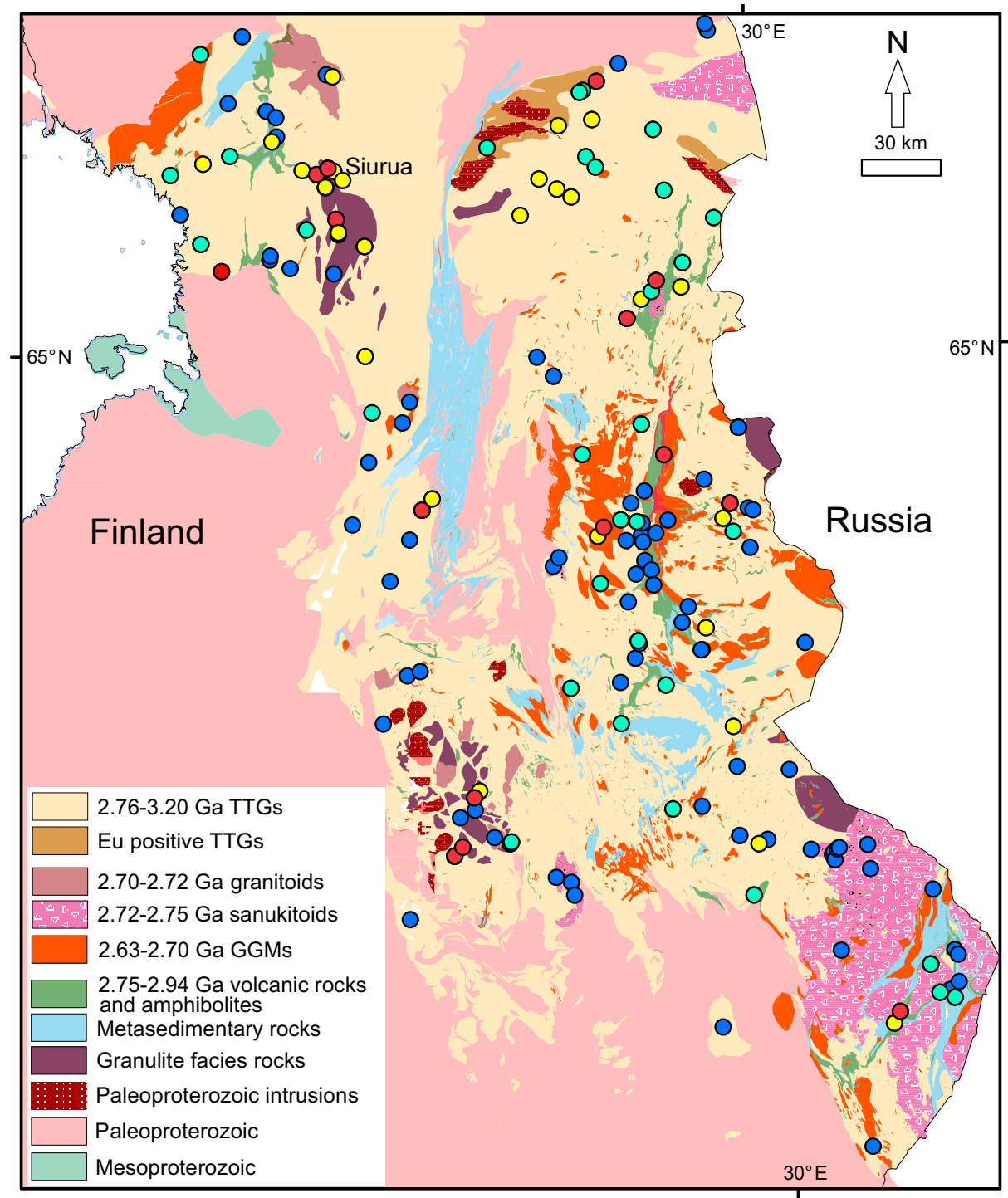


Finland in the data by Huhma et al. (2012). With a few exceptions, the zircon ages of these rocks are 2.65-2.84 Ga. In many samples, throughout the area, the model ages are $>3.0 \mathrm{Ga}$, indicating that these granitoids comprise substantial abundances of reworked or recycled material.

The distribution of the $\varepsilon_{\mathrm{Nd}}(\mathrm{t})$ and $\mathrm{t}_{\mathrm{DM}}$ model ages in the Archean of eastern Finland (Fig. 9) is very similar to that in the TTGs of the northeastern Superior Province. There, the negative $\varepsilon_{\mathrm{Nd}}$ values have been related to crustal reworking, where the subsequent felsic magmas remelted and assimilated older crust, with the proportion of granitoids gradually increasing so much that the crust eventually became continental (Boily et al. 2009; Maurice et al. 2009; O’Neil \& Carlson 2017; Bédard 2018). This type of process could also explain the observed isotopic age distribution of the Archean crust in the Karelia Province. The oldest, 3.20-3.50 Ga TTGs could represent small magma chambers in a mafic crust into which high volumes of TTG melts were later introduced in several pulses. In fact, quite significant volumes of the felsic Archean crust are highly migmatitic amphibolites, which could be remnants of the early mafic crust (Hölttä et al. 2012). TTG melts were largely juvenile, but some of these assimilated existing crustal material or represent melting of the older crustal rocks. The abundance of 2.90$3.00 \mathrm{Ga}$ zircon grains in many samples suggests that a sialic crust could have already covered large areas at this time in the area of the present Karelia Province.

Our data include many zircon grains dated at $2.60-2.70 \mathrm{Ga}$. These are interpreted as metamorphic, although not all of these have a low $\mathrm{Th} / \mathrm{U}$ ratio $(<0.1)$, typical for metamorphic zircon. However, if no other Th-bearing phases were present during the zircon growth, metamorphic zircon can also be relatively Th-rich (Rubatto 2017). Another possibility for the $\leq 2.70$ ages is $\mathrm{Pb}$ loss caused by 2.60-2.70 Ga metamorphism, also observed by Lauri et al. (Lauri et al. 2011). Earlier age determinations have shown that during this period, intensive migmatization, GGM magmatism and high-grade metamorphism took place in the
Karelia Province. The age distribution of zircon suggesting that this event could have lasted for almost 100 My ( Hölttä et al. 2000b; Hölttä \& Paavola 2000; Mänttäri \& Hölttä 2002; Käpyaho et al. 2006; 2007; Lauri et al. 2011; Mikkola et al. 2012). Presumably, the crust was heated enough to cause $\mathrm{Pb}$ loss in many zircon grains that are seemingly concordant or near concordant in the concordia diagram but in fact represent $\mathrm{Pb}$ loss. The analyses yielding a spread of concordant ages between 2.7.5-2.88 Ga, e.g., in sample A1888, are difficult to interpret, but the explanation could be ancient $\mathrm{Pb}$ loss caused by strong metamorphism at 2.60-2.70 Ga.

\subsection{Tectonic implications}

The Archean felsic crust of the Karelia Province has been considered to be dominantly Neoarchean $(<2.85 \mathrm{Ga})$ based on the existing age determinations (Hölttä et al. 2012, 2014). The tectonic position of the few observed $3.00-3.50 \mathrm{Ga}$ gneisses is poorly constrained and they have been thought to represent allochthonous small fragments, accreted to the Neoarchean crust at around 2.70 (Hölttä et al. 2019), or a thin Paleoarchean protocrust (Heilimo et al. 2011; Mikkola et al. 2011). Mints et al. (2014, 2015) argued for the existence of Mesoarchean microcontinents as constituents of the Archean crust. Our results, together with the earlier age determinations, indicate that in western Karelia, the Paleoarchean, 3.20-3.50 Ga gneisses do not form large coherent areas. However, the present structure is mainly the result of Neoarchean and also Proterozoic thrusting and folding, which could have totally reorganized the structure of the Mesoarchean crust, so that the old coherent microcontinents are now just rootless small allochthons in the Neoarchean crust.

Overviews on the geochemical and tectonic evolution of the Archean granitoids have been presented in many publications (Martin et al. 2005; Moyen 2009, 2011; Laurent et al. 2014). In general, TTGs are considered to originate from partial melting of hydrous mafic precursors. Many 
TTGs, although not all, show adakitic geochemical characteristics with low HREE and high Sr/Y and $\mathrm{La} / \mathrm{Yb}$ ratios. These features have been related to the melting of basaltic rocks at high pressures (>1.5 GPa), where plagioclase is not stable, but the abundance of garnet is high in the source.

However, possible causes for the adakite-like geochemistry could also be the high $\mathrm{Sr} / \mathrm{Y}$ ratio of the source and interactions of the sialic melts with the mantle. Moreover, in aluminous and Fe-rich compositions, garnet can be stable at much lower pressures of 0.5-1.0 GPa (Moyen 2009). Therefore, in TTGs, the high $\mathrm{Sr} / \mathrm{Y}$ ratio alone is not a good indicator of the depth at which the granitoid melts were generated.

Moyen (2011) and Moyen \& Martin (2012) classified the Archean TTGs into low (1.0-1.2 $\mathrm{GPa}$ ), medium (ca. $1.5 \mathrm{GPa}$ ) and high pressure $(\geq 2.0 \mathrm{GPa}$ ) types based on melting depth, reflected by $\mathrm{Al}_{2} \mathrm{O}_{3}, \mathrm{Na}_{2} \mathrm{O}, \mathrm{HREE}, \mathrm{Sr}$ and HFSE contents and ratios. When the compositions of our samples are plotted on his discrimination diagrams, most of them suggest medium and high pressure melting at ca. $15 \mathrm{kbar}$ and $\geq 20 \mathrm{kbar}$, respectively (Electronic Appendix J). Only the tonalite sample A1890 from Taivalkoski clearly falls into the low-pressure group according to most geochemical criteria.

Halla et al. (2009) divided the TTGs into low-HREE and high-HREE groups, the former representing melting of amphibolites at a high pressure and the latter melting at shallower depths. In a large number of analyses from the western Karelia Province, the TTGs show a continuous spread from low to high HREE, Sr/Y and La/Yb (Rasilainen et al. 2007, Hölttä et al. 2012). This suggests that their melting depth was highly variable between ca. 35 and $>70 \mathrm{~km}$, and, as suggested by the zircon and whole-rock $\mathrm{Nd}$ data, the trace element budget was also controlled by contamination of the TTG melts by an older sialic crust.

In our data, the TTGs geochemically representing certain melting depths do not correlate with the age. However, the 2.70-2.74 Ga tonalites and trondhjemites from the Iisalmi and Pudasjärvi areas show the highest $\varepsilon_{\mathrm{Nd}}(\mathrm{t})$ values, representing the most juvenile crustal components. In their large data set on Archean zircon, Griffin et al. (2014) found significant increases in juvenile material at ca. 2.75 and ca. $2.50 \mathrm{Ga}$, which they interpreted to mark a change in the geodynamic setting, possibly mantle overturn and the advent of modern-style plate tectonics, related to the assembly of the Kenorland supercontinent. Our data suggest that signs of this process are also seen in the Karelia Province.

The tectonic setting for the generation of the TTG melts has been disputable, and the discussion on their origin has been closely related to the onset of modern-style plate tectonics. Basically, there are two major views on the origin of the TTG melts: one is the anatexis of basalts at the base of a thick mafic crust and the other is melting in subduction environments (Martin et al. 2014; Bédard 2018; Jain et al. 2019). Numerical modelling has supported both interpretations (van Hunen \& van den Berg 2008; Halla et al. 2009; Sizova et al. 2015; Rozel et al. 2017; Jain et al. 2019; Piccolo et al. 2019; Roman \& Arndt 2019;). Nebel et al. (2018) have also argued that TTG melts can be generated, without modern-style subduction, in lower crustal drips driven by convection in the underlying mantle.

In the Karelia Province, the Archean mantle is exposed in the Jormua ophiolite complex, where Peltonen et al. (2003) described Paleoproterozoic alkaline dykes with inherited Archean zircons whose ages are from 2.75-3.2 Ga (Fig. 10). Although the number of Archean zircon grains was low $(\mathrm{n}=13)$ in their data set, the ages correspond quite well with the age spread of the TTGs in our data and also elsewhere in the NW Karelia Province (Fig. 10, (Hölttä et al. 2012)). Archean zircon grains in the dykes may represent recycled crustal material carried into the mantle by late Archean slab-driven subduction or by vertical or drip tectonics related with mantle convection, as proposed by Nebel et al. (2018) and Jain et al. (2019). 


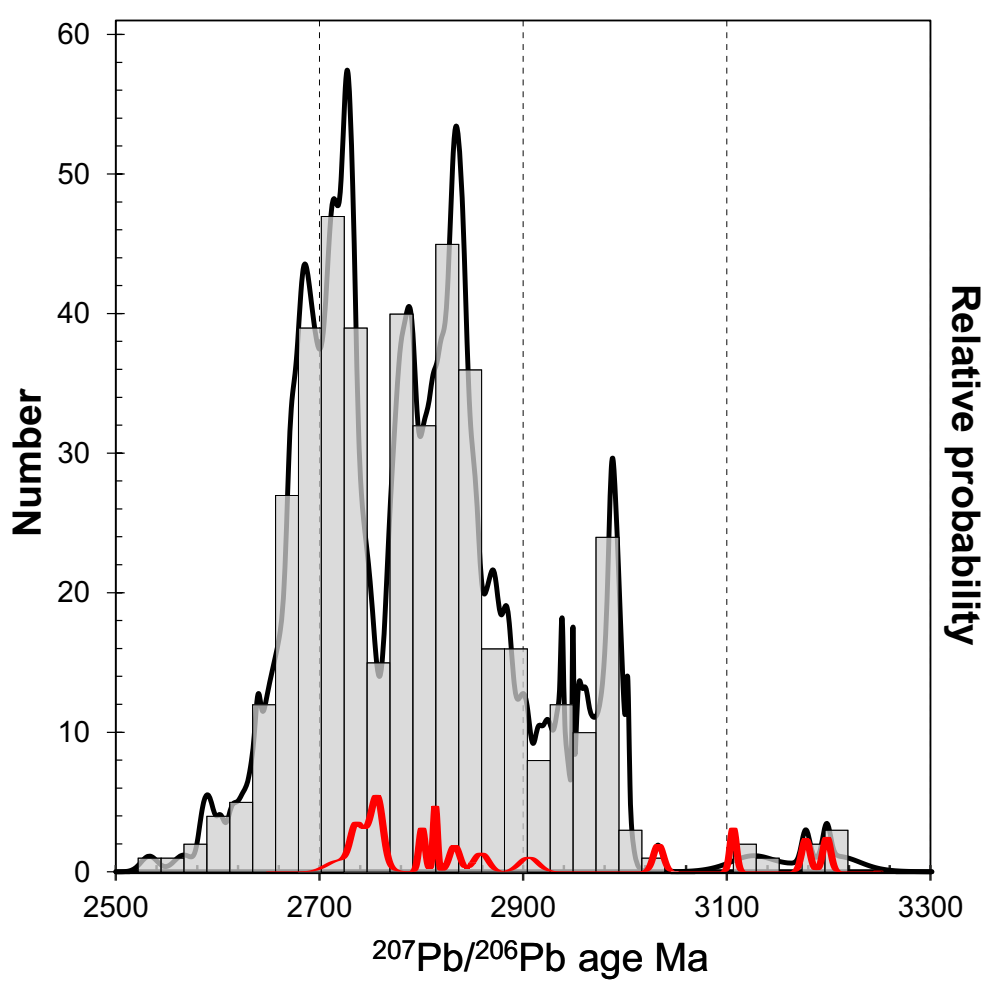

Figure 10. Relative probability plot of concordant or near-concordant ${ }^{207} \mathrm{~Pb} /{ }^{206} \mathrm{~Pb}$ ages on zircon in this study and the data by Peltonen et al. 2003) (in red).

\section{Conclusions}

- The oldest, 3.40-3.50 Ga gneisses are only small fragments in the Neoarchean environment.

- Adakitic geochemical signatures do not correlate with the age, but in general the Neoarchean, 2.72-2.74 Ga TTGs represent the most juvenile magmas, presumably representing deep melting.

- The Archean sialic crust in the western Karelia Province was largely formed from juvenile Neoarchean melts, but the abundance of 2.90-3.00 Ga zircons in most TTGs, as well as the low initial $\varepsilon_{\mathrm{Nd}}$ values in some of these, suggests that the TTG melts commonly assimilated older crustal material.

\section{Acknowledgements}

Tuula Hokkanen, Jenni Keränen and Arto Pulkkinen are thanked for their assistance with the isotopic analyses, and Martin Whitehouse for help with the Nordsim. The Geological Survey of Finland is acknowledged for the funding of the NORDSIM work. The constructive reviews by Hervé Martin, Sanjeet K. Verma and anonymous reviewers greatly improved the original manuscript. The English language was revised by Dr Roy Siddall.

\section{Supplementary data}

Electronic Appendices A-J for this article are available via Bulletin of the Geological Society of Finland web page. 


\section{References}

Balagansky, V., Shchipansky, A., Slabunov, A. I., Gorbunov, I., Mudruk, S., Sidorov, M., Azimov, P., Egorova, S., Stepanova, A. \& Voloshin, A. 2015. Archaean KuruVaara eclogites in the northern Belomorian Province, Fennoscandian Shield: crustal architecture, timing, and tectonic implications. International Geology Review 57, 1543-1565.

https://doi.org/10.1080/00206814.2014.958578

Barker, F. 1979. Trondhjemite: Definition, environment and hypotheses of origin. In F. Barker (Ed.), Trondhjemites, Dacites, and Related Rocks. Elsevier, Amsterdam, pp. 1-12.

Bédard, J. H. 2018. Stagnant lids and mantle overturns: Implications for Archaean tectonics, magmagenesis, crustal growth, mantle evolution, and the start of plate tectonics. Geoscience Frontiers 9, 19-49.

https://doi.org/10.1016/j.gsf.2017.01.005

Boily, M., Leclair, A., Maurice, C., Bédard, J. H. \& David, J. 2009. Paleo- to Mesoarchean basement recycling and terrane definition in the Northeastern Superior Province, Québec, Canada. Precambrian research 168, 23-44. https://doi.org/10.1016/j.precamres.2008.07.009

Boynton, W. R. 1984. Cosmochemistry of the rare earth elements meteorite studies. In P. Henderson (Ed.), Rare Earth Element Geochemistry. Elsevier, Amsterdam, pp. 63-114.

Dokukina, K. A. \& Mints, M. 2019. Subduction of the Mesoarchaean spreading ridge and related metamorphism, magmatism and deformation by the example of the Gridino eclogitized mafic dyke swarm, the Belomorian Eclogite Province, eastern Fennoscandian Shield. Journal of Geodynamics 123, 1-37. https://doi.org/10.1016/j.jog.2018.11.003

Dokukina, K. A., Mints, M. V. \& Konilov, A. N. 2017. Melting of eclogite facies sedimentary rocks in the Belomorian Eclogite Province, Russia. Journal of Metamorphic Geology 35, 435-451. https://doi.org/10.1111/jmg.12239

Griffin, W., Belousova, E., O’Neil, C., O’Reilly, S., Malkoverts, V., Pearson, N., Spetsius, S. \& Wilde, S. 2014. The world turns over: Hadean-Archean crust-mantle evolution. Lithos 189, 2-15.

https://doi.org/10.1016/j.lithos.2013.08.018

Halla, J. 2005. Late Archean high-Mg granitoids (sanukitoids) in the southern Karelian domain, eastern Finland: $\mathrm{Pb}$ and $\mathrm{Nd}$ isotopic constraints on crust-mantle interactions. Lithos 79, 161-178. https://doi.org/10.1016/j.lithos.2004.05.007

Halla, J., van Hunen, J., Heilimo, E. \& Hölttä, P. 2009. Geochemical and numerical constraints on Neoarchean plate tectonics. Precambrian Research 174, 155-162. https://doi.org/10.1016/j.precamres.2009.07.008

Heilimo, E., Halla, J. \& Hölttä, P. 2010. Discrimination and origin of the sanukitoid series: geochemical constraints from the Neoarchean western Karelian Province (Finland). Lithos 115, 27-39.

https://doi.org/10.1016/j.lithos.2009.11.001

Heilimo, E., Halla, J. \& Huhma, H. 2011. Single-grain zircon $\mathrm{U}-\mathrm{Pb}$ age constraints of the western and eastern sanukitoid zones in the Finnish part of the Karelian Province. Lithos 121, 87-99. https://doi.org/10.1016/j.lithos.2010.10.006

Heilimo, E., Halla, J. \& Mikkola, P. 2012. Overview of Neoarchaean sanukitoid series in the Karelia Province, eastern Finland. Special Paper of the Geological Survey of Finland 54, 214-225.

http://tupa.gtk.fi/julkaisu/specialpaper/sp_054_ pages_214_225.pdf

Heilimo, E., Halla, J., Andersen, T. \& Huhma, H. 2013. Neoarchean crustal recycling and mantle metasomatism: $\mathrm{Hf}-\mathrm{Nd}-\mathrm{Pb}-\mathrm{O}$ isotope evidence from sanukitoids of the Fennoscandian shield. Precambrian Research 228, 250266. https://doi.org/10.1016/j.precamres.2012.01.015

Hölttä, P. 1997. Geochemical characteristics of granulite facies rocks in the Archean Varpaisjärvi area, central Fennoscandian Shield. Lithos 40, 31-53. https://doi.org/10.1016/S0024-4937(96)00025-4

Hölttä, P. \& Paavola, J. 2000. P-T-t development of Archaean granulites in Varpaisjärvi, central Finland. I. Effects of multiple metamorphism on the reaction history of mafic rocks. Lithos 50, 97-120. https://doi.org/10.1016/S0024-4937(99)00056-0

Hölttä, P., Huhma, H., Mänttäri, I. \& Paavola, J. 2000a. $\mathrm{P}-\mathrm{T}-\mathrm{t}$ development of Archaean granulites in Varpaisjärvi, Central Finland. Lithos 50, 121-136. https://doi.org/10.1016/S0024-4937(99)00055-9

Hölttä, P., Huhma, H., Mänttäri, I. \& Paavola, J. 2000b. P-T-t development of Archaean granulites in Varpaisjärvi, central Finland. II. Dating of high-grade metamorphism with the U-Pb and Sm-Nd methods. Lithos 50, 121-136. https://doi.org/10.1016/S0024-4937(99)00055-9

Hölttä, P., Heilimo, E., Huhma, H., Kontinen, A., Mertanen, S., Mikkola, P., Paavola, J., Peltonen, P., Semprich, J., Slabunov, A. \& Sorjonen-Ward, P. 2012. The Archaean of the Karelia Province in Finland. Special Paper of the Geological Survey of Finland 54, 21-73.

Hölttä, P., Heilimo, E., Huhma, H., Kontinen, A., Mertanen, S., Mikkola, P., Paavola, J., Peltonen, P., Semprich, J., Slabunov, A. \& Sorjonen-Ward, P. 2014. The Archaean Karelia and Belomorian Provinces, Fennoscandian Shield. In Y. Dilek, \& H. Furnes (Eds.), Evolution of Archean Crust and Early Life. Springer, Dordrecht, pp. 55-102.

Hölttä, P., Heilimo, E., Huhma, H., Kontinen, A., Lauri, L. \& Slabunov, A. I. 2019. Paleoarchean rocks in the Fennoscandian Shield. In M. Kranendonk, \& J. E. Hoffmann (Eds.), Earth's Oldest Rocks. Elsevier, Amsterdam, pp. 819-836.

Huhma, H., Mänttäri, I., Peltonen, P., Kontinen, A., Halkoaho, T., Hanski, E., Hokkanen, T., Hölttä, P., Juopperi, H., Konnunaho, J., Lahaye, Y., Luukkonen, E., Pietikäinen, 
K., Pulkkinen, A., Sorjonen-Ward, P., Vaasjoki, M. \& Whitehouse, M. 2012a. The age of the Archaean greenstone belts in Finland. Special Paper of the Geological Survey of Finland 54, 74-175.

Huhma, H., Kontinen, A., Mikkola, P., Halkoaho, T., Hokkanen, T., Hölttä, P., Juopperi, H., Konnunaho, J., Luukkonen, E., Mutanen, T., Peltonen, P., Pietikäinen, K. \& Pulkkinen, A. 2012b. Nd isotopic evidence for Archaean crustal growth in Finland. Special Paper of the Geological Survey of Finland 54, 176-214.

Jain, C., Rozel, A. B., Tackley, P. J., Sanan, P. \& Gerya, T. V. 2019. Growing primordial continental crust selfconsistently in global mantle convection models. Gondwana Research 73, 96-122. https://doi.org/10.1016/j.gr.2019.03.015

Käpyaho, A., Hölttä, P. \& Whitehouse, M. J. 2007. U-Pb zircon geochronology of selected Archaean migmatites in eastern Finland. Bulletin of the Geological Society of Finland 79, 95-115. https://doi.org/10.17741/bgsf/79.1.005

Käpyaho, A., Mänttäri, I. \& Huhma, H. 2006. Growth of Archaean crust in the Kuhmo district, eastern Finland: $\mathrm{U}-\mathrm{Pb}$ and $\mathrm{Sm}-\mathrm{Nd}$ isotope constraints on plutonic rocks. Precambrian Research 146, 95-119.

https://doi.org/10.1016/j.precamres.2006.01.006

Koistinen, T., Stephens, M. B., Bogatchev, V., Nordgulen, Ø, Wennerström, M. \& Korhonen, J. 2001. Geological map of the Fennoscandian Shield, scale 1:2000000. Geological Survey of Finland, Espoo, Finland.

Kontinen, A., Käpyaho, A., Huhma, H., Karhu, J., Matukov, D. I., Larionov, A. \& Sergeev, S. A. 2007. Nurmes paragneisses in eastern Finland, Karelian craton: Provenance, tectonic setting and implications for Neoarchaean craton correlation. Precambrian Research 152, 119-148.

https://doi.org/10.1016/j.precamres.2006.11.001

Laajoki, K. 1991. Stratigraphy of the northern end of the early Proterozoic (Karelian) Kainuu Schist Belt and associated gneiss complexes, Finland. Geological Survey of Finland, Bulletin 358, 1-105.

https:/tupa.gtk.fi/julkaisu/bulletin/bt_358.pdf

Lalli, K. 2002. Pudasjärven granuliittivyöhykkeen Isokummun alueen petrografia, geokemia ja metamorfinen petrologia. Oulu Mining School, Geosciences, University of Oulu, unpublished MSc Thesis.

Laurent, O., Martin, H., Moyen, J. \& Doucelance, R. 2014. The diversity and evolution of late-Archean granitoids: Evidence for the onset of "modern-style" plate tectonics between 3.0 and 2.5 Ga. Lithos 205, 208-235. https://doi.org/10.1016/j.lithos.2014.06.012

Lauri, L. S., Rämö, O. T., Huhma, H., Mänttäri, I. \& Räsänen, J. 2006. Petrogenesis of silicic magmatism related to the 2.44 Ga rifting of Archean crust in Koillismaa, eastern Finland. Lithos 86, 137-166.

https://doi.org/10.1016/j.lithos.2005.03.016

Lauri, L. S., Andersen, T., Hölttä, P., Huhma, H. \& Graham, S. 2011. Evolution of the Archaean Karelian Province in the Fennoscandian Shield in the light of U-Pb zircon ages and $\mathrm{Sm}-\mathrm{Nd}$ and Lu-Hf isotope systematics. Journal of the Geological Society 168, 201-218.

https://doi.org/10.1144/0016-76492009-159

Lehtonen, E., Heilimo, E., Halkoaho, T., Käpyaho, A. \& Hölttä, P. 2016. U-Pb geochronology of Archaean volcanic-sedimentary sequences in the Kuhmo greenstone belt, Karelia Province-Multiphase volcanism from Meso- to Neoarchaean and a Neoarchaean depositional basin? Precambrian Research 275, 48-69. https://doi.org/10.1016/j.precamres.2015.12.002

Lehtonen, E., Heilimo, E., Halkoaho, T., Hölttä, P. \& Huhma, H. 2017. The temporal variation of Mesoarchaean volcanism in the Suomussalmi greenstone belt, Karelia Province, Eastern Finland. International Journal of Earth Sciences 106, 763-781. https://doi.org/10.1007/s00531-016-1327-y

Lobach-Zhuchenko, S. B., Rollinson, H. R., Chekulaev, V. P., Arestova, N. A., Kovalenko, A. V., Ivanikov, V. V., Guseva, N. S., Sergeev, S. A., Matukov, D. I. \& Jarvis, K. E. 2005. The Archaean sanukitoid series of the Baltic Shield: geological setting, geochemical characteristics and implications for their origin. Lithos 79, 107-128. https://doi.org/10.1016/j.lithos.2004.04.052

Ludwig, K. R. 2012. User's Manual for Isoplot 3.75. A Geochronological Toolkit for Microsoft Excel. Berkeley Geochronology Center, Special Publication 5, 1-75.

https://www.yumpu.com/en/document/ view/41106214/users-manual-for-berkeleygeochronology-center

Maier, W. D., Peltonen, P., Halkoaho, T. \& Hanski, E. 2013. Geochemistry of komatiites from the Tipasjärvi, Kuhmo, Suomussalmi, Ilomantsi and Tulppio greenstone belts, Finland: Implications for tectonic setting and Ni sulphide prospectivity. Precambrian Research 228, 63-84. https:// doi.org/10.1016/j.precamres.2012.12.004

Mänttäri, I. \& Hölttä, P. 2002. U-Pb dating of zircons and monazites from Archean granulites in Varpaisjärvi, central Finland: evidence for multiple metamorphism and Neoarchean terrane accretion. Precambrian Research $118,101-131$. https://doi.org/10.1016/S0301-9268(02)00094-3

Martin, H., Smithies, R. H., Rapp, R., Moyen, J. \& Champion, D. 2005. An overview of adakite, tonalite-trondhjemitegranodiorite (TTG), and sanukitoid: relationships and some implications for crustal evolution. Lithos 79, 1-24. https://doi.org/10.1016/j.lithos.2004.04.048

Martin, H., Moyen, J., Guitreau, M., Blichert-Toft, J. \& Le Pennec, J. 2014. Why Archaean TTG cannot be generated by MORB melting in subduction zones. Lithos 198-199, 1-13.

https://doi.org/10.1016/j.lithos.2014.02.017

Mattinson, J. M. 2005. Zircon U-Pb chemical abrasion ("CATIMS”) method: Combined annealing and multi-step partial dissolution analysis for improved precision and accuracy of zircon ages. Chemical Geology 220, 47-66. https://doi.org/10.1016/j.chemgeo.2005.03.011 
Maurice, C., David, J., Bédard, J. H. \& Francis, D. 2009. Evidence for a widespread mafic cover sequence and its implications for continental growth in the Northeastern Superior Province. Precambrian Research 168, 45-65. https://doi.org/10.1016/j.precamres.2008.04.010

Mikkola, P., Huhma, H., Heilimo, E. \& Whitehouse, M. 2011. Archean crustal evolution of the Suomussalmi district as part of the Kianta Complex, Karelia: Constraints from geochemistry and isotopes of granitoids. Lithos 125, 287-307. https://doi.org/10.1016/j.lithos.2011.02.012

Mikkola, P., Lauri, L. S. \& Käpyaho, A. 2012. Neoarchean leucogranitoids of the Kianta Complex, Karelian Province, Finland: source characteristics and processes responsible for the observed heterogeneity. Precambrian Research 206-207,72-86. https://doi.org/10.1016/j.precamres.2012.02.010

Mints, M. 2014. Tectonics and geodynamics of granulite-gneiss complexes in the East European Craton. Geotectonics 48, 496-522. https://doi.org/10.1134/S0016852114060089

Mints, M., Konilov, A., Dokukina, K., Kaulina, T., Belousova, E., Natapov, L., Griffin, W. \& O'Reilly, S. 2010. The Belomorian eclogite province: Unique evidence of MesoNeoarchaean subduction and collision. Doklady Earth Sciences 434, 1311-1316. https://doi.org/10.1134/S1028334X10100053

Mints, M. V., Dokukina, K. A., Konilov, A. N., Kaulina, T. V., Belousova, E. A., Dokukin, P. A., Natapov, L. M. \& Van, K. V. 2015. Mesoarchean Kola-Karelia continent. Geological Society of America Special Papers 510, 15-88.

Moyen, J. 2009. High Sr/Y and La/Yb ratios: The meaning of the "adakitic signature". Lithos 112, 556-574. https://doi.org/10.1016/j.lithos.2009.04.001

Moyen, J. 2011. The composite Archaean grey gneisses: Petrological significance, and evidence for a non-unique tectonic setting for Archaean crustal growth. Lithos 123, 21-36. https://doi.org/10.1016/j.lithos.2010.09.015

Moyen, J. \& Martin, H. 2012. Forty years of TTG research. Lithos 148, 312-336.

https://doi.org/10.1016/j.lithos.2012.06.010

Mutanen, T. \& Huhma, H. 2003. The $3.5 \mathrm{Ga}$ Siurua trondhjemite gneiss in the Archaean Pudasjärvi Granulite Belt, northern Finland. Bulletin of the Geological Society of Finland 75, 51-68. https://doi.org/10.17741/bgsf/75.1-2.004

Nebel, O., Capitanio, F. A., Moyen, J., Weinberg, R. F., Clos, F., Nebel-Jacobsen, Y. J., Cawood, P. A. \& ois. 2018. When crust comes of age: on the chemical evolution of Archaean, felsic continental crust by crustal drip tectonics. Philosophical transactions of the Royal Society of London. Series A: Mathematical, physical, and engineering sciences 376, 20180103. https://doi.org/10.1098/rsta.2018.0103

O'Brien, H., Heilimo, E. \& Heino, P. 2015. The Archean Siilinjärvi Carbonatite Complex. In W. D. Maier, R. Lahtinen \& H. O'Brien (Eds.), Mineral Deposits of Finland. Elsevier, Amsterdam, pp. 327-343.
O’Neil, J. \& Carlson, R. W. 2017. Building Archean cratons from Hadean mafic crust. Science 355, 1199-1202. https://doi.org/10.1126/science.aah3823

Paavola, J. 2003. Vieremän kartta-alueen kallioperä. Summary: Pre-Quaternary rocks of the Vieremä map-sheet area. Geological Map of Finland 1:100 000. Explanation to the maps of Pre-Quaternary rocks. Sheet 3342 Vieremä. Geological Survey of Finland, Espoo, Finland. https://tupa.gtk.fi/kartta/kallioperakartta100/kps_3342. pdf

Peltonen, P., Manttari, I., Huhma, H. \& Kontinen, A. 2003. Archean zircons from the mantle; the Jormua Ophiolite revisited. Geology (Boulder) 31, 645-648. https://doi.org/10.1130/0091-7613(2003)0312.0.CO;2

Piccolo, A., Palin, R. M., Kaus, B. J. P. \& White, R. W. 2019. Generation of Earth's Early Continents From a Relatively Cool Archean Mantle. Geochemistry, Geophysics, Geosystems 20, 1679-1697. https://doi.org/10.1029/2018GC008079

Pietikäinen, K. \& Vaasjoki, M. 1999. Structural observations and $\mathrm{U}-\mathrm{Pb}$ mineral ages from igneous rocks at the Archaean-Palaeoproterozoic boundary in the Salahmi Schist Belt, central Finland: constraints on tectonic evolution. Bulletin of the Geological Society of Finland 71, 133-142. https://doi.org/10.17741/bgsf/71.1.006

Rasilainen, K., Lahtinen, R. \& Bornhorst, T. J. 2007. The Rock Geochemical Database of Finland Manual. Geological Survey of Finland, Report of Investigation 184, 38. http://tupa.gtk.fi/julkaisu/tutkimusraportti/tr_164.pdf

Roman, A. \& Arndt, N. 2019. Differentiated Archean oceanic crust: Its thermal structure, mechanical stability and a test of the sagduction hypothesis. Geochimica et Cosmochimica Acta 278, 65-77. https://doi.org/10.1016/j.gca.2019.07.009

Rozel, A. B., Golabek, G. J., Jain, C., Tackley, P. J. \& Gerya, T. 2017. Continental crust formation on early Earth controlled by intrusive magmatism. Nature 545, 332 335. https://doi.org/10.1038/nature22042

Rubatto, D. 2017. Zircon: The Metamorphic Mineral. Reviews in Mineralogy \& Geochemistry 83, 261-295.

Ruotoistenmäki, T. 2019. Adakitic plutonic rocks in the Finnish Precambrian: Evolution and areal, chemical, physical and age variations. Geological Survey of Finland, Special Publications 102, 1-146. http://tupa.gtk.fi/julkaisu/erikoisjulkaisu/ej_102.pdf

Sergeev, S., Bibikova, E., Matukov, D. \& Lobach-Zhuchenko, S. 2007. Age of the magmatic and metamorphic processes in the Vodlozero Complex, Baltic Shield: An ion microprobe (SHRIMP II) U-Th-Pb isotopic study of zircons. Geochemistry International 45, 198-205. https://doi.org/10.1134/S0016702907020097

Sergeev, S., Lobach-Zhuchenko, S., Arestova, N., Tolmacheva, E., Berezhnaya, N., Matukov, D., Lokhov, K. \& Antonov, A. 2008. Age and geochemistry of zircons from the ancient granitoids of the Vyg River, Southeastern Karelia. Geochemistry International 46, 595-607. https://doi.org/10.1134/S0016702908060050 
Shchipansky, A. A., Samsonov, A. V., Bibikova, E. V., Babarina, I. I., Konilov, A. N., Krylov, K. A., Slabunov, A. I. \& Bogina, M. M. 2004. 2.8 Ga boninite-hosting partial suprasubduction ophiolite sequences from the North Karelian greenstone belt, NE Baltic Shield, Russia. In T. M. Kusky (Ed.), Precambrian Ophiolites and Related Rocks. Elsevier, Amsterdam, pp. 425-487.

Sizova, E., Gerya, T., Stüwe, K. \& Brown, M. 2015. Generation of felsic crust in the Archean: A geodynamic modeling perspective. Precambrian Research 271, 198-224. https://doi.org/10.1016/j.precamres.2015.10.005

Slabunov, A. I., Lobach-Zhuchenko, S. B., Bibikova, E. V., Balagansky (Balaganskiy), V. V., Sorjonen-Ward, P., Volodichev, O. I., Shchipansky (Shchipanskiy), A. A., Svetov, S. A., Chekulaev (Chekulayev), V. P., Arestova, N. A. \& Stepanov, V. S. 2006. The Archean of the Baltic Shield; geology, geochronology, and geodynamic settings. Geotectonics 40, 409-433.

https://doi.org/http://dx.doi.org/10.1134/ S001685210606001X

Smol'kin, V., Sharkov, E., Lokhov, K., Kapitonov, I. \& Sergeev, S. 2011. Genesis of high-magnesium volcanic rocks of the Paleoproterozoic Vetrennyi Belt (Eastern Karelia): Evidence from the study of U-Pb and Lu-Hf systems in zircons. Doklady Earth Sciences 439, 1093-1098. https://doi.org/10.1134/S1028334X1108006X

Stacey, J. S. \& Kramers, J. D. 1975. Approximation of terrestrial lead isotope evolution by a two-stage model. Earth and Planetary Science Letters 26, 207-221. https://doi.org/10.1016/0012-821X(75)90088-6

Sun, S. S. \& McDonough, W. F. 1989. Chemical and isotopic systematics of oceanic basalts: implications for mantle composition and processes. Geological Society Special Publication 42, 313-345. https://doi.org/10.1144/GSL.SP.1989.042.01.19

Svetov, S. A., Huhma, H., Svetova, A. I. \& Nazarova, T. N. 2004. The oldest adakites of the Fennoscandian Shieeld. Doklady Earth Sciences 397A, 878-882.

Svetov, S., Kudryashov, N., Ronkin, Y., Huhma, H., Svetova, A. \& Nazarova, T. 2006. Mesoarchean island-arc association in the Central Karelian terrane, Fennoscandian shield:
New Geochronological data. Doklady Earth Sciences 406, 103-106.

https://doi.org/10.1134/S1028334X06010259

Vaasjoki, M., Sorjonen-Ward, P. \& Lavikainen, S. 1993. U-Pb age determinations and sulfide $\mathrm{Pb}-\mathrm{Pb}$ characteristics from the late Archean Hattu schist belt, Ilomantsi, eastern Finland. Special Paper of the Geological Survey of Finland 17, 103-131.

http://tupa.gtk.fi/julkaisu/specialpaper/sp_017_ pages_103_131.pdf

Vaasjoki, M., Kärki, A. \& Laajoki, K. 2001. Timing of Palaeoproterozoic crustal shearing in the central Fennoscandian Shield according to U-Pb data from associated granitoids, Finland. Bulletin of the Geological Society of Finland 73, 87-101. https://doi.org/10.17741/bgsf/73.1-2.007

van Hunen, J. \& van den Berg, A. P. 2008. Plate tectonics on the early Earth: Limitations imposed by strength and buoyancy of subducted lithosphere. Lithos 103, 217-235. https://doi.org/10.1016/j.lithos.2007.09.016

Volodichev, O. I., Slabunov, A. I., Bibikova, E. V., Konilov, A. N. \& Kuzenko, T. I. 2004. Archean eclogites in the Belomorian mobile belt, Baltic Shield. Petrology 12, 540560.

Whitehouse, M. J. \& Kamber, B. S. 2005. Assigning Dates to Thin Gneissic Veins in High-Grade Metamorphic Terranes: A Cautionary Tale from Akilia, Southwest Greenland. Journal of Petrology 46, 291-318. https://doi.org/10.1093/petrology/egh075

Whitehouse, M. J., Kamber, B. S. \& Moorbath, S. 1999. Age significance of U-Th-Pb zircon data from early Archaean rocks of west Greenland-a reassessment based on combined ion-microprobe and imaging studies. Chemical Geology 160, 201-224. https://doi.org/10.1016/S0009-2541(99)00066-2

Wiedenbeck, M., Allé, P., Corfu, F., Griffin, W. L., Meier, M., Oberli, F., Qaedt, A. v., Roddick, J. C. \& Spiegel, W. 1995. Three natural zircon standards for U-Th-Pb, Lu-Hf, trace element and REE analysis. Geostandards Newsletter $19,1-23$.

https://doi.org/10.1111/j.1751-908X.1995.tb00147.x 